\title{
CAPILLARY BLOOD PRESSURE IN MAN. DIRECT MEASUREMENTS IN THE DIGITS OF NORMAL AND HYPERTENSIVE SUBJECTS DURING VASOCONSTRICTION AND VASODILATATION VARIOUSLY INDUCED ${ }^{1,2}$
}

\author{
By LUDWIG W. EICHNA AND JAMES BORDLEY, III \\ (From the Department of Medicine, The Johns Hopkins University School of Medicine, \\ Baltimore)
}

(Received for publication June 1, 1942)

The normal cardiac output (1) in essential hypertension implies a normal "total" blood flow to the entire body. The elevated arterial pressure has, therefore, been attributed to an increase in the "total" resistance of the vascular system. The arterioles are considered to contribute the major portion of this increased resistance.

Correlated determinations of arterial and capillary blood pressures in normal and hypertensive subjects should reveal the nature and location of the vascular resistance in hypertension. In hypertensive states, the capillary blood pressure has been measured ( 2 to 5 ), but by indirect methods, the reliability of which has been questioned (6). It seemed advisable, therefore, to study the capillary blood pressure of normal and hypertensive subjects by the accurate, direct, micro-injection method (Landis) (7), and to make the observation not only under resting conditions but also during influences known to alter the circulation in the areas under study.

\section{METHODS}

The capillary blood pressure was determined in the nail-folds of the fingers. The direct micro-injection method (Landis) $(7,6)$ was employed throughout.

General. All of the methods, conditions, and precautions, fully described in a previous communication (8) under the general category of methods, were rigidly maintained in the present study. This pertained to equipment, surroundings, and subjects.

Particular. Only pressures obtained when the blood flow in the capillaries remained visibly unaltered are recorded as capillary blood pressures. At times, capillaries were so pierced that the micropipette obstructed completely the lumen of the capillary. Blood flow

1 Supported by a grant from The Commonwealth Fund for the study of essential hypertension.

2 A preliminary report of these observations was read by title at the annual meeting of The American Society for Clinical Investigation, May 5, 1941 (J. Clin. Invest., 1941, 20, 458). through the capillary ceased. Blood now entered the micropipette from one limb of the capillary and was expelled into the same limb when pressure in the micropipette was raised. The micropipette and capillary-limb acted jointly as a tube leading to the next most adjacent blood channel, arteriole, or venule. Equilibrium between micropipette-pressure and capillary blood pressure under these circumstances was believed to indicate the pressure in the nearest arteriole or venule. Readings obtained under these conditions are termed "arteriole" blood pressure and "venule" blood pressure, respectively.

Each value of capillary blood pressure indicated the pressure in a single capillary, and was obtained by averaging the individual values of a series of readings made during a single continuous observation on that capillary. Single readings which could not be checked by successive readings have been discarded as lacking sufficient reliability. Each value of arteriole or venule blood pressure was obtained in a similar manner.

Observations were made on 3 groups of subjects. (1) Subjects with normal arterial pressures: normal individuals and patients convalescing from illnesses not associated with circulatory disturbances, hereafter termed normal subjects. (2) Patients with elevated arterial pressures: excepting 1 patient with acute nephritis, these subjects had essential hypertension; the majority were of the benign type, several were of the malignant type. (3) Subjects with low arterial pressure, either in association with their systemic illnesses, or as a result of local arterial disease, were included in the normal group. In no patient in any group, was there evidence of congestive heart failure or of an increase in venous pressure.

\section{RESULTS}

In both normal and hypertensive subjects, considerable variation in digital capillary blood pressure was found; not only from individual to individual but also in the same subject from day to day and even in adjacent capillaries of the same nail-fold during a single experiment. During moderate vasodilatation of the digital circulation, alterations in capillary blood pressure were occasionally observed during a single series of readings throughout which the micropipette remained in the same location in a given capillary. Similar 
TABLE I

Capillary blood pressure during two series of measurements in the same location of the same capillary during a single experiment

\begin{tabular}{|c|c|c|c|c|c|c|c|c|}
\hline \multirow{2}{*}{$\begin{array}{c}\text { Subject } \\
\text { (Sex, age) }\end{array}$} & \multirow{2}{*}{ Diagnosis } & \multirow{2}{*}{$\begin{array}{l}\text { Skin tem- } \\
\text { perature }\end{array}$} & \multirow{2}{*}{$\begin{array}{l}\text { Arterial } \\
\text { presuure }\end{array}$} & \multirow{2}{*}{$\begin{array}{c}\text { Location } \\
\text { where capillary } \\
\text { blood pressure } \\
\text { was measured }\end{array}$} & \multirow{2}{*}{$\begin{array}{l}\text { Interval be- } \\
\text { tween readings }\end{array}$} & \multicolumn{3}{|c|}{ Capillary blood pressure } \\
\hline & & & & & & First series & Second series & Difference \\
\hline $\begin{array}{l}\text { M. E. } \\
(\mathrm{F}, 30)\end{array}$ & Normal & $\begin{array}{l}{ }^{\circ} c . \\
33.5\end{array}$ & $\begin{array}{c}\operatorname{mm} . H_{g} \\
116 / 78\end{array}$ & Summit & $\begin{array}{l}\text { minutes } \\
26\end{array}$ & $\underset{25.5}{\operatorname{mm} . H_{g}}$ & $\operatorname{mm}_{33} H_{E}$ & $\begin{array}{c}m m . H_{g} \\
7.5\end{array}$ \\
\hline$\underset{(\mathrm{F}, \mathbf{2 8})}{\mathrm{S}}$ & $\begin{array}{l}\text { Essential } \\
\text { hyperten- } \\
\text { sion }\end{array}$ & $\begin{array}{l}34.4 \\
34.4 \\
33.7\end{array}$ & $\begin{array}{l}164 / 110 \\
164 / 110 \\
168 / 110\end{array}$ & $\begin{array}{l}\text { Venous limb } \\
\text { Venous limb } \\
\text { Venous limb }\end{array}$ & $\begin{array}{r}18 \\
13 \\
7\end{array}$ & $\begin{array}{l}18 \\
23 \\
28\end{array}$ & $\begin{array}{l}20 \\
18 \\
38\end{array}$ & $\begin{array}{r}2 \\
5 \\
10\end{array}$ \\
\hline$\underset{(F, 38)}{T .}$ & $\begin{array}{l}\text { Essential } \\
\text { hyperten- } \\
\text { sion }\end{array}$ & 35.9 & $156 / 110$ & Arteriole & 11 & 46 & 47 & 1 \\
\hline $\begin{array}{l}\text { V. M. } \\
(\mathrm{F}, 29)\end{array}$ & $\begin{array}{l}\text { Essential } \\
\text { hyperten- } \\
\text { sion }\end{array}$ & 31.1 & $164 / 120$ & $\begin{array}{c}\text { Arteriolar } \\
\operatorname{limb}\end{array}$ & 23 & 28 & 28.5 & 0.5 \\
\hline$\underset{(F, \mathbf{F} 3)}{\mathrm{L}}$ & $\begin{array}{l}\text { Essential } \\
\text { hyperten- } \\
\text { sion }\end{array}$ & $\begin{array}{l}35.3 \\
30.5\end{array}$ & $\begin{array}{l}170 / 120 \\
166 / 114\end{array}$ & $\begin{array}{l}\text { Arteriolar } \\
\text { limb } \\
\text { Arteriolar } \\
\text { limb }\end{array}$ & $\begin{array}{l}15 \\
44\end{array}$ & $\begin{array}{l}23 \\
10.5^{*}\end{array}$ & $\begin{array}{l}22 \\
28^{*}\end{array}$ & $\begin{array}{r}1.0 \\
17.5\end{array}$ \\
\hline$\underset{(F, 29)}{\text { H. B. }}$ & $\begin{array}{l}\text { Essential } \\
\text { hyperten- } \\
\text { sion }\end{array}$ & 34.0 & $160 / 114$ & Summit & 10 & 30 & 33 & 3 \\
\hline
\end{tabular}

Arterial pressure and skin temperature essentially unaltered during the two series of readings.

* In this experiment skin temperature rose from $30.5^{\circ} \mathrm{C}$. to $32.2^{\circ} \mathrm{C}$. and arterial pressure from $166 / 114$ to $174 / 120$ between the two series of readings.

variations also occurred during reflex vasodilatation, a state considered to be associated with a relatively constant digital circulation. Repiercing the same capillary in the same location, at intervals throughout a single experiment, yielded capillary blood pressures which were usually comparable (Table I). At times large differences were observed between determinations, even when an effort was made to keep the digital circulation constant (Table I).

\section{Effect of increased local venous pressure}

A previous study (6) confirmed the observations of Landis (7), that induced increases in local venous pressure were accompanied by rises in capillary blood pressure to values which exceeded the venous pressure.

Including the cases already reported (6), the capillary blood pressure was measured in the same location, in the same capillary, at normal and elevated digital venous pressures, in 22 subjects with varying arterial pressures (Table II). In all subjects, the capillary blood pressure in all lo- cations of the capillary rose, in most instances to exceed local venous pressure by $1 \mathrm{~mm}$. $\mathrm{Hg}$ to 15 $\mathrm{mm}$. Hg. The response of the capillary blood pressure to increases in venous pressure was similar in both hypertensive and normal subjects (Table II).

\section{Effect of vasoconstriction in the digits}

Another study (8) showed that neurogenic digital vasoconstrictions were accompanied by decreases in digital capillary blood pressure, which in 4 hypertensive patients were of approximately the same duration and magnitude as in 3 normal subjects (Figure 1). Neither reflex vasodilatation nor the local hyperemia induced by the intradermal injection of histamine acid phosphate (1:100 in salt solution) prevented these falls in capillary blood pressure in normal or hypertensive subjects (8).

\section{Effect of digital skin temperature}

No determinations were made of the capillary blood pressure in the same capillary during sig- 
nificant changes in digital skin temperature. However, the temperature of the digital pad was determined at the time of each capillary blood pressure measurement. Therefore, some correlation of these two factors is possible (Figures 2 and 3 ).

With the hands moderately warm, capillary blood pressure seemed unaffected by digital skin temperature. At all skin temperatures between $27^{\circ} \mathrm{C}$. and $35^{\circ} \mathrm{C}$., the capillary blood pressures in all locations of the capillary scattered widely, and approximately equally, in both normal (Figure 2) and hypertensive (Figure 3 ) subjects. In both groups of subjects, the degree of variation was much the same at the lower as at the higher temperatures within this range. At the warmer skin temperatures, slightly higher capillary blood pressures were obtained in both the arteriolar and venous limbs of the hypertensive patients than in the normal subjects. These differences were not definite. Only at very low skin temperatures did the digital capillary blood pressure fall below the limits obtained during moderate digital vasodilatation. For example, in one hypertensive subject, the capillary blood pressure in the arteriolar limb fell to $7.5 \mathrm{~mm}$. $\mathrm{Hg}$ when the digital skin temperature was $24.8^{\circ} \mathrm{C}$. Blood flow through the capillary at this time was abnormally slow.

Gradient of fall of pressure in the capillary

The capillary blood pressure was determined in 60 subjects with normal arterial pressures, in 46

TABLE II

The effect of locally increased oenous pressure upon the blood pressure in the same capillary

\begin{tabular}{|c|c|c|c|c|c|c|c|c|}
\hline \multirow{2}{*}{$\begin{array}{c}\text { Subject } \\
\text { (Sex } \\
\text { age) }\end{array}$} & \multirow{2}{*}{ Diagnoeis } & \multirow{2}{*}{$\begin{array}{l}\text { Arterial } \\
\text { preasure }\end{array}$} & \multirow{2}{*}{$\begin{array}{c}\text { Stin } \\
\text { temperature }\end{array}$} & \multirow{2}{*}{$\begin{array}{l}\text { Location in } \\
\text { capillary } \\
\text { where } \\
\text { preserere was } \\
\text { measured }\end{array}$} & \multicolumn{2}{|c|}{$\underset{\text { pressure }}{\text { Capillary blood }}$} & \multirow{2}{*}{ Cuff preseure* } & \multirow{2}{*}{$\begin{array}{l}\text { Difference be } \\
\text { tween capillary } \\
\text { blood pressure } \\
\text { and cuff } \\
\text { pressure } \\
\text { during venous } \\
\text { congestion }\end{array}$} \\
\hline & & & & & Initial & $\begin{array}{c}\text { During } \\
\text { venous } \\
\text { congestion }\end{array}$ & & \\
\hline $\begin{array}{l}\text { I. B. } \\
(\mathbf{F}, 19)\end{array}$ & Normal & $\begin{array}{l}\operatorname{mm.} B g \\
116 / 72\end{array}$ & ${ }^{\circ} \mathrm{C} .{ }^{\circ}$ & Arteriolar limb & $\operatorname{mm.~}_{19}$ & $\begin{array}{c}m m . B_{\ell} \\
54 \text { to } 60\end{array}$ & $\operatorname{m4}^{m m^{\prime} B_{\ell}}$ & $\begin{array}{l}m m . B s \\
+10\end{array}$ \\
\hline$\underset{(\mathrm{F}, \mathrm{13})}{\mathrm{B} .}$ & Diabetes mellitus & $\begin{array}{l}92 / 62 \\
92 / 62 \\
92 / 62 \\
\end{array}$ & $\begin{array}{l}29.0 \\
31.1 \\
31.1 \\
\end{array}$ & $\begin{array}{l}\text { Venous limb } \\
\text { Venous limb } \\
\text { Venous limb } \\
\end{array}$ & $\begin{array}{l}12 \\
13 \\
19 \\
\end{array}$ & $\begin{array}{l}51.5 \\
51.5 \\
61.5 \\
\end{array}$ & $\begin{array}{l}53(51.8) \\
52 \\
51 \\
\end{array}$ & $\begin{array}{r}-1.5 \\
=0.5 \\
+10.5 \\
\end{array}$ \\
\hline$\underset{(\mathbf{M}, 15)}{\mathrm{H} . \mathrm{B}}$ & $\begin{array}{l}\text { Convalescent } \\
\text { rheumatic } \\
\text { heart disease }\end{array}$ & $116 / 76$ & 28.1 & Arteriolar limb & 22 & 58.5 & $52(46.5)$ & +6.5 \\
\hline$\underset{(\mathbf{F}, \mathbf{2 5})}{\mathbf{H} . \mathbf{B}}$ & Syphilis & $80 / 50$ & 31.1 & Venous limb & 11.5 & 46 & $44(42.8)$ & +2.0 \\
\hline$\underset{(\mathbf{F}, \mathbf{2 6})}{\mathbf{H} . \mathbf{G}}$ & Normal & $112 / 82$ & 29.7 & Summit & 53 & 62.5 & 61 & +1.5 \\
\hline $\begin{array}{c}\text { C. J. } \\
(\mathbf{M}, 47) \\
\end{array}$ & Normal & $\begin{array}{l}112 / 82 \\
112 / 82 \\
\end{array}$ & $\begin{array}{l}29.7 \\
29.7 \\
\end{array}$ & $\begin{array}{l}\text { Arteriolar limb } \\
\text { Arteriolar limb } \\
\end{array}$ & 20 & $\begin{array}{l}76 \\
60 \\
\end{array}$ & $\begin{array}{l}80 \\
59 \\
\end{array}$ & $\begin{array}{r}-4.0 \\
+1.0 \\
\end{array}$ \\
\hline$\underset{(\mathbf{F}, \mathbf{3 1})}{\text { M. }}$ & $\begin{array}{c}\text { Convalescent } \\
\text { otitis media }\end{array}$ & $\begin{array}{l}106 / 76 \\
106 / 76\end{array}$ & $\begin{array}{l}29.6 \\
29.8\end{array}$ & $\begin{array}{l}\text { Arteriolar limb } \\
\text { Venous limb }\end{array}$ & $\begin{array}{l}35 \\
35.5\end{array}$ & $\begin{array}{l}69.5 \\
68\end{array}$ & $\begin{array}{l}60(57.8) \\
60(57.8)\end{array}$ & $\begin{array}{l}+9.5 \\
+8.0\end{array}$ \\
\hline $\begin{array}{c}\text { G. M. } \\
(\mathbf{M}, 19)\end{array}$ & Normal & $\begin{array}{l}126 / 74 \\
116 / 76\end{array}$ & $\begin{array}{l}27.1 \\
28.9\end{array}$ & $\begin{array}{l}\text { Venous limb } \\
\text { Venous limb }\end{array}$ & $\begin{array}{l}14 \\
11\end{array}$ & $\begin{array}{l}39 \\
49.5\end{array}$ & $\begin{array}{l}36 \\
46\end{array}$ & $\begin{array}{l}+3.0 \\
+3.5\end{array}$ \\
\hline $\begin{array}{c}\mathbf{W} . \mathbf{O}_{(\dot{1}} \\
(\mathbf{M}, 25)\end{array}$ & Normal & $124 / 66$ & 30.5 & Venous limb & 13 & 49 & 50 & -1.0 \\
\hline$\underset{(\mathbf{M}, 21)}{E . ~ R .}$ & Normal & $\begin{array}{l}130 / 76 \\
130 / 76\end{array}$ & $\begin{array}{l}30.0 \\
30.0\end{array}$ & $\begin{array}{l}\text { Arteriolar limb } \\
\text { Arteriolar limb }\end{array}$ & $\begin{array}{l}41 \\
36\end{array}$ & $\begin{array}{l}66 \\
68\end{array}$ & $\begin{array}{l}52 \\
52\end{array}$ & $\begin{array}{l}+14 \\
+16\end{array}$ \\
\hline$\underset{(\mathbf{M}, \mathbf{3 2})}{\mathrm{W}}$ & $\begin{array}{c}\text { Convalescent } \\
\text { pneumonia }\end{array}$ & $104 / 60$ & 28.9 & Venous limb & 23.5 & 54 & $54(47.9)$ & 0.0 \\
\hline$\underset{(\mathbf{F}, \mathbf{4 1})}{\mathbf{H} . \mathbf{G}}$ & Raynaud's disease & $\begin{array}{l}110 / 74 \\
110 / 74\end{array}$ & $\begin{array}{l}27.3 \\
27.3\end{array}$ & $\begin{array}{l}\text { Arteriolar limb } \\
\text { Summit }\end{array}$ & $\begin{array}{l}12 \\
13\end{array}$ & $\begin{array}{l}41 \\
44\end{array}$ & $\begin{array}{l}40 \\
43\end{array}$ & $\begin{array}{l}+1.0 \\
+1.0\end{array}$ \\
\hline
\end{tabular}


TABLE II-Continued

\begin{tabular}{|c|c|c|c|c|c|c|c|c|}
\hline \multirow{2}{*}{$\begin{array}{l}\text { Subject } \\
\text { (Sex } \\
\text { age) }\end{array}$} & \multirow{2}{*}{ Diagnoeis } & \multirow{2}{*}{$\begin{array}{l}\text { Arterial } \\
\text { pressure }\end{array}$} & \multirow{2}{*}{ Stemperature } & \multirow{2}{*}{$\begin{array}{l}\text { Location in } \\
\text { capillary } \\
\text { where } \\
\text { presesure was } \\
\text { measured }\end{array}$} & \multicolumn{2}{|c|}{$\begin{array}{c}\text { Capillary blood } \\
\text { pressure }\end{array}$} & \multirow{2}{*}{ Cuff pressure* } & \multirow{2}{*}{$\begin{array}{l}\text { Difference be- } \\
\text { tween capillary } \\
\text { blood presure } \\
\text { and cuffe } \\
\text { pressure } \\
\text { during venous } \\
\text { congestion }\end{array}$} \\
\hline & & & & & Initial & $\begin{array}{c}\text { During } \\
\text { venoug } \\
\text { congestion }\end{array}$ & & \\
\hline $\begin{array}{l}\text { M. L. } \\
(\mathbf{F}, \mathbf{4 8})\end{array}$ & $\begin{array}{l}\text { Raynaud's disease } \\
\text { with scleroderma }\end{array}$ & $\begin{array}{l}\operatorname{mm.Hg} \\
110 / 72 \\
108 / 62 \\
110 / 72 \\
110 / 72 \\
\end{array}$ & $\begin{array}{l}{ }^{\circ} C . \\
26.5 \\
23.8 \\
33.0 \\
33.0\end{array}$ & $\begin{array}{l}\text { Venous limb } \\
\text { Venous limb } \\
\text { Arteriolar limb } \\
\text { Venous limb }\end{array}$ & $\begin{array}{c}m m . H g \\
18 \\
20 \\
20 \\
19\end{array}$ & $\begin{array}{c}\operatorname{mm.} . \mathrm{Bg} \\
60 \\
67.5 \\
64 \\
62\end{array}$ & $\begin{array}{l}\operatorname{mm} . H_{g} \\
60(57.9) \\
63 \\
60 \\
61\end{array}$ & $\begin{array}{r}m m . ~ B g \\
0.0 \\
+4.5 \\
+4.0 \\
+\quad 1.0\end{array}$ \\
\hline$\underset{(\mathbf{M}, \mathbf{3 i})}{\mathbf{F} . \mathbf{G}}$ & Raynaud's disease & $\begin{array}{l}130 / 76 \\
130 / 76 \\
118 / 66 \\
118 / 66\end{array}$ & $\begin{array}{l}25.7 \\
28.1 \\
28.1 \\
30.3 \\
30.3\end{array}$ & $\begin{array}{l}\text { Venous limb } \\
\text { Venous limb } \\
\text { Venous } \operatorname{limb} \\
\text { Venous } \operatorname{limb} \\
\text { Venous } \operatorname{limb}\end{array}$ & $\begin{array}{l}16.5 \\
35 \\
22 \\
20 \\
14\end{array}$ & $\begin{array}{l}52 \\
73 \\
66 \\
53.5 \\
38.5\end{array}$ & $\begin{array}{l}52(47.1) \\
63 \\
61 \\
54 \\
43\end{array}$ & $\begin{array}{r}0.0 \\
+10.0 \\
+5.0 \\
+\quad 0.5 \\
-4.5\end{array}$ \\
\hline$\underset{(\mathbf{M}, 35)}{\text { C. B. }}$ & Hypertension & $222 / 148$ & 35.0 & Summit & 52 & 128 & 82 & +46.0 \\
\hline$\underset{(\mathrm{M}, \mathbf{4 1})}{\mathrm{J} .}$ & ? Hypertension & $148 / 90$ & 28.6 & Venous limb & 15 & 50 & 50 & 0.0 \\
\hline$\underset{(F, 29)}{\text { H. B. }}$ & Hypertension & $166 / 130$ & 27.7 & Venous limb & 14 & 66 & 63 & +3.0 \\
\hline $\begin{array}{l}\text { W. E. } \\
(\mathbf{M}, \mathbf{5 0})\end{array}$ & Hypertension & $200 / 118$ & 29.0 & Venous limb & 29 & 58 & 52 & +6.0 \\
\hline$\underset{(F, 36)}{H}$ & Hypertension & $220 / 140$ & 30.2 & Venous limb & 18 & 52 & 52 & 0.0 \\
\hline$\underset{(\mathbf{F}, \mathbf{3 3})}{\text { F. }}$ & Hypertension & $\begin{array}{l}174 / 114 \\
174 / 114 \\
192 / 128 \\
192 / 128\end{array}$ & $\begin{array}{l}32.7 \\
32.7 \\
31.5 \\
31.5\end{array}$ & $\begin{array}{l}\text { Venous limb } \\
\text { Venous limb } \\
\text { Venous limb } \\
\text { Venous limb }\end{array}$ & $\begin{array}{c}12 \\
18 \\
22 \\
\text { not } \\
\text { deter- } \\
\text { mined }\end{array}$ & $\begin{array}{r}63 \\
83 \\
95 \\
102\end{array}$ & $\begin{array}{r}60 \\
80 \\
90 \\
190 \\
9\end{array}$ & $\begin{array}{l}+3.0 \\
+3.0 \\
+5.0 \\
+12.0\end{array}$ \\
\hline$\underset{(\mathrm{F}, 23)}{\mathrm{N} .}$ & Hypertension $\$$ & $174 / 110$ & 31.5 & Venous limb & 14 & 77 & 80 & -3.0 \\
\hline$\underset{(\mathbf{M}, \mathbf{3 6})}{\mathrm{J}}$ & Hypertension & $236 / 146$ & 30.3 & Arteriolar limb & 49 & 82 & 81 & +1.0 \\
\hline
\end{tabular}

* Local venous pressure usually fell several $\mathrm{mm}$. $\mathrm{Hg}$ below cuff pressure. Figures in parentheses give the actually determined venous pressure at the cuff pressure indicated by the immediately preceding figure.

patients with essential hypertension, and in one patient with acute nephritis. In the "normal" group, the arterial pressure averaged 119/74 (mean pressure $96 \mathrm{~mm}$. Hg). Systolic pressure ranged from $80 \mathrm{~mm}$. $\mathrm{Hg}$ to $156 \mathrm{~mm}$. $\mathrm{Hg}$, and diastolic pressure, from $50 \mathrm{~mm}$. $\mathrm{Hg}$ to $98 \mathrm{~mm}$. $\mathrm{Hg}$. In the hypertensive group, the average arterial pressure was $188 / 124$ (mean pressure $156 \mathrm{~mm}$. $\mathrm{Hg}$ ) ; the systolic pressure varied from $132 \mathrm{~mm}$. $\mathrm{Hg}$ to 254 $\mathrm{mm}$. $\mathrm{Hg}$, and the diastolic pressure, from $96 \mathrm{~mm}$. $\mathrm{Hg}$ to $186 \mathrm{~mm}$. $\mathrm{Hg}$. In one subject with multiple aneurysms, the arterial pressure was unobtainable.

In both groups of subjects, the wide variations in the capillary blood pressure for the same loca- tion in the capillary led to considerable overlapping of the values for arteriolar and venous limbs. Nevertheless, the values for corresponding locations in the capillary were approximately the same in both the hypertensive and normal subjects ( $\mathrm{Ta}$ ble III). The scattering and overlapping were less marked when determinations were made during a single experiment on adjacent capillaries. At such times, the values for the two limbs of the capillaries were both in the same range, with the arteriolar limb pressure usually exceeding slightly the venous limb pressure.

Assuming the average values for each location in the capillary to be representative of the capil- 


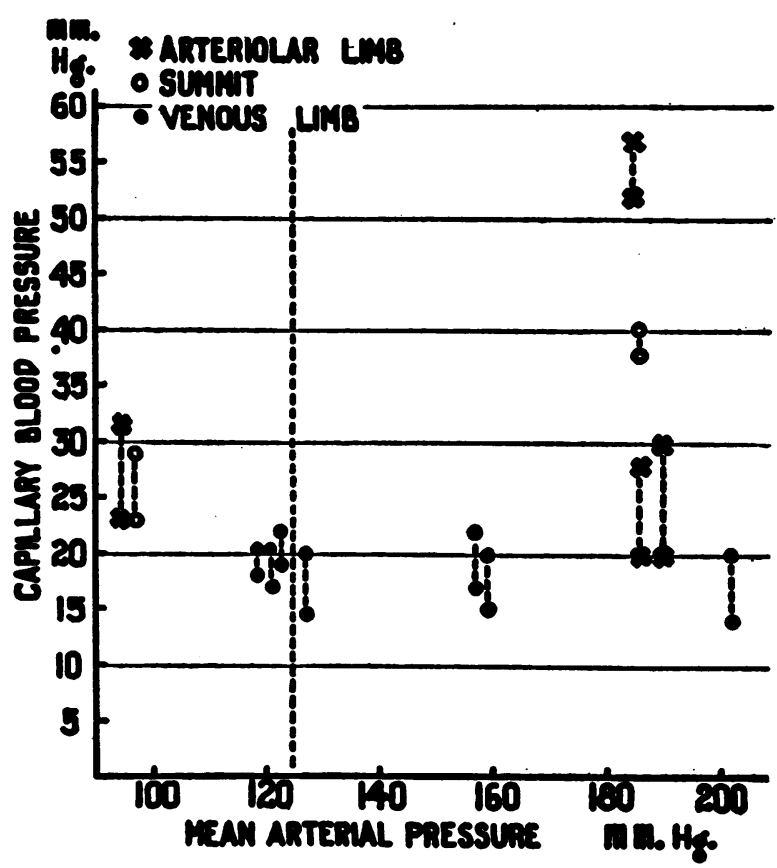

Fig. 1. Changes in Capillary Blood Pressure in the Same Capillary in Normal and Hypertensive Subjects Following Neurogenic Vasoconstrictor Stimuli

Following the stimuli the pressures always fell, and approximately equally in both groups of subjects.

\section{Construction of charts}

All charts. Ordinates; always capillary blood pressure in $\mathrm{mm}$. Hg. Abscissae; usually mean arterial pressure in $\mathrm{mm}$. $\mathrm{Hg}$, except Figures 2,3 (skin temperature ${ }^{\circ} \mathrm{C}$.). The long, vertical, dotted line indicates the upper limit of normal mean arterial pressure.

Scatter charts. (Figures 2, 3, 4, 6, 7, 9.) Each dot represents the average digital capillary blood pressure in the designated location in a single capillary at the mean arterial pressure or skin temperature indicated by the abscissa. Each heavy horizontal arrow and number above the abscissa line indicates the average of all of the pressures represented by the corresponding dots.

Charts of changes in single capillaries. (Figures 1, 8.) Digital capillary blood pressures in the same location of the same capillary are connected by vertical lines. When the lines are solid, the pressure rose from the lower to the higher value; when dotted, the pressure fell from the higher to the lower value.

lary blood pressure in that location for the group, then the gradient of fall of pressure from arteriolar limb to venous limb was $8.7 \mathrm{~mm}$. $\mathrm{Hg}$ (30.6 mm. $\mathrm{Hg}$ to $21.9 \mathrm{~mm}$. $\mathrm{Hg}$ ) in the "normal" subjects, and $13.1 \mathrm{~mm}$. $\mathrm{Hg}(35.9 \mathrm{~mm}$. $\mathrm{Hg}$ to $22.8 \mathrm{~mm}$. $\mathrm{Hg}$ ) in the hypertensive subjects. An increase of 50.5 per cent in the hypertensive subjects. But, when the gradient of pressure was measured in the same capillary, no significant difference was found in the gradient between corresponding locations of the capillary in 9 normal and 12 hypertensive subjects (Table IV).

In both normal and hypertensive subjects, the gradient of fall of pressure from "arteriole" to "venule" was more marked than the gradient from arteriolar limb to venous limb of the capillary (Figure 4).

The average arteriole-venule gradient for the normal subjects was $38.1 \mathrm{~mm}$. $\mathrm{Hg}$, for the hypertensive subjects $34.9 \mathrm{~mm}$. $\mathrm{Hg}$. In a few instances, both arteriole and venule blood pressure in the hypertensive subjects exceeded the highest values obtained in normal subjects. There was no correlation between arteriole or venule blood pressure and the mean arterial pressure.

\section{Digital capillary blood pressure during procedures designed to dilate the arterioles}

Reflex vasodilatation. Although reflex vasodilatation is associated with a constant, reproducible, and maximal digital skin temperature, digital capillary blood pressure determined during this state still varied widely in both normal and hypertensive subjects (Figure 5). Even during a single experiment, throughout which digital skin temperature was maintained at the maximum level, considerable variation persisted in the digital capillary blood pressures measured in the same location of adjacent capillaries of a given individual. The limits of this variation and the average capillary blood pressures for both arteriolar and venous limbs were practically the same in the few hypertensive and normal subjects studied (Figure 5). Moreover, the range of variation during maximal reflex vasodilatation approximated that obtained during moderate digital vasodilatation.

During maximal reflex vasodilatation the average capillary blood pressure in the venous limb exceeded values obtained during the resting state, but the average pressure in the arteriolar limb remained unchanged (Figures 5, 2, and 3). As a result, the gradient of pressure from arteriolar limb to venous limb of the capillary became less steep : $2 \mathrm{~mm}$. $\mathrm{Hg}$ in the normal subjects, practically zero in the hypertensive subjects. It is 
known that the digital blood flow during this state is, nevertheless, much increased.

Reactive hyperemia. The digital capillary blood pressure was always determined in the same location in the same capillary during reactive hyperemia as it had been during the resting state. With circulatory arrest, the blood continued to flow for 5 to 10 seconds, then stopped. It gradually became dark blue, more compact and seemingly more viscid, as indicated by its more sluggish movement in, and adherence to, the micropipette tip. Apparently, the red blood cells packed together, presumably as a result of the loss of plasma fluid. In the summits of 2 capillaries of a patient with Raynaud's disease, the digital capillary blood pressure at this time measured $11 \mathrm{~mm}$. $\mathrm{Hg}$ and 13 $\mathrm{mm} . \mathrm{Hg}$.

On release of the circulation, the mass of packed red blood cells tended to adhere to the wall of the capillary and, at times, several seconds elapsed before the mass was pushed onward and blood flow became reestablished. Sticking of the erythrocytes to the wall of the capillary was observed most frequently in those capillaries which had been previously pierced several times. Occasionally, it was necessary to prod the tissue about the capillary with the micropipette before the red blood cells moved forward and swift blood flow returned to the capillary. At times, even this procedure did not suffice, and the capillary 'remained "permanently" in stasis. During reactive hyperemia, the capillaries appeared very pink but not particularly dilated.

The above findings were similar in normal and hypertensive subjects.

In the few studies on the normal sized capillaries of normal and hypertensive subjects, digital capillary blood pressure during reactive hyperemia was essentially the same as during the resting state (Table V). The differences between pressures

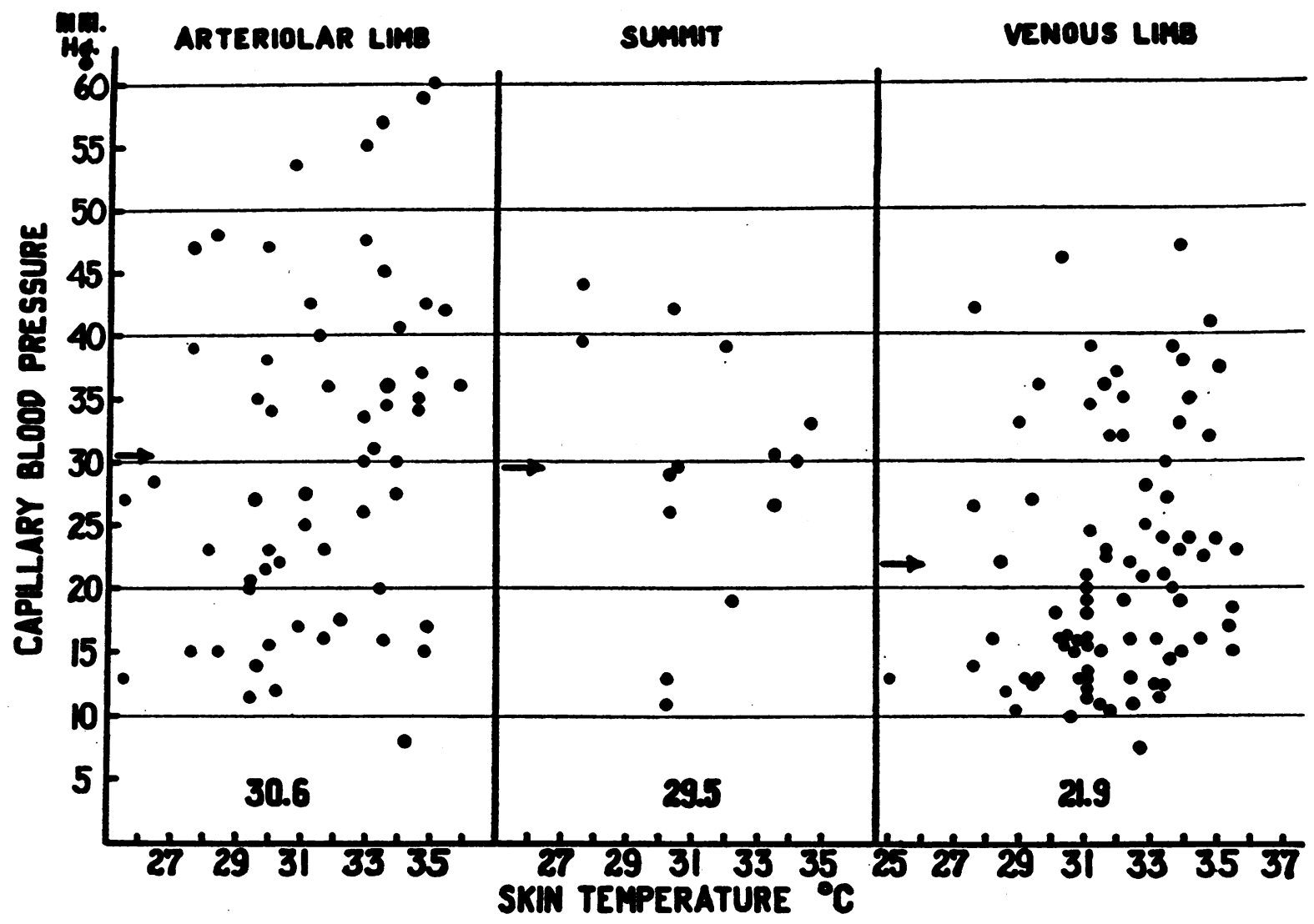

Fig. 2. Digital Capillary Blood Pressure in Different locations in the Capillary at Varying Levels of Digital Skin Temperature. Subjects with Normal Arterial Pressure

The range of pressures is the same at both low and high skin temperatures. 


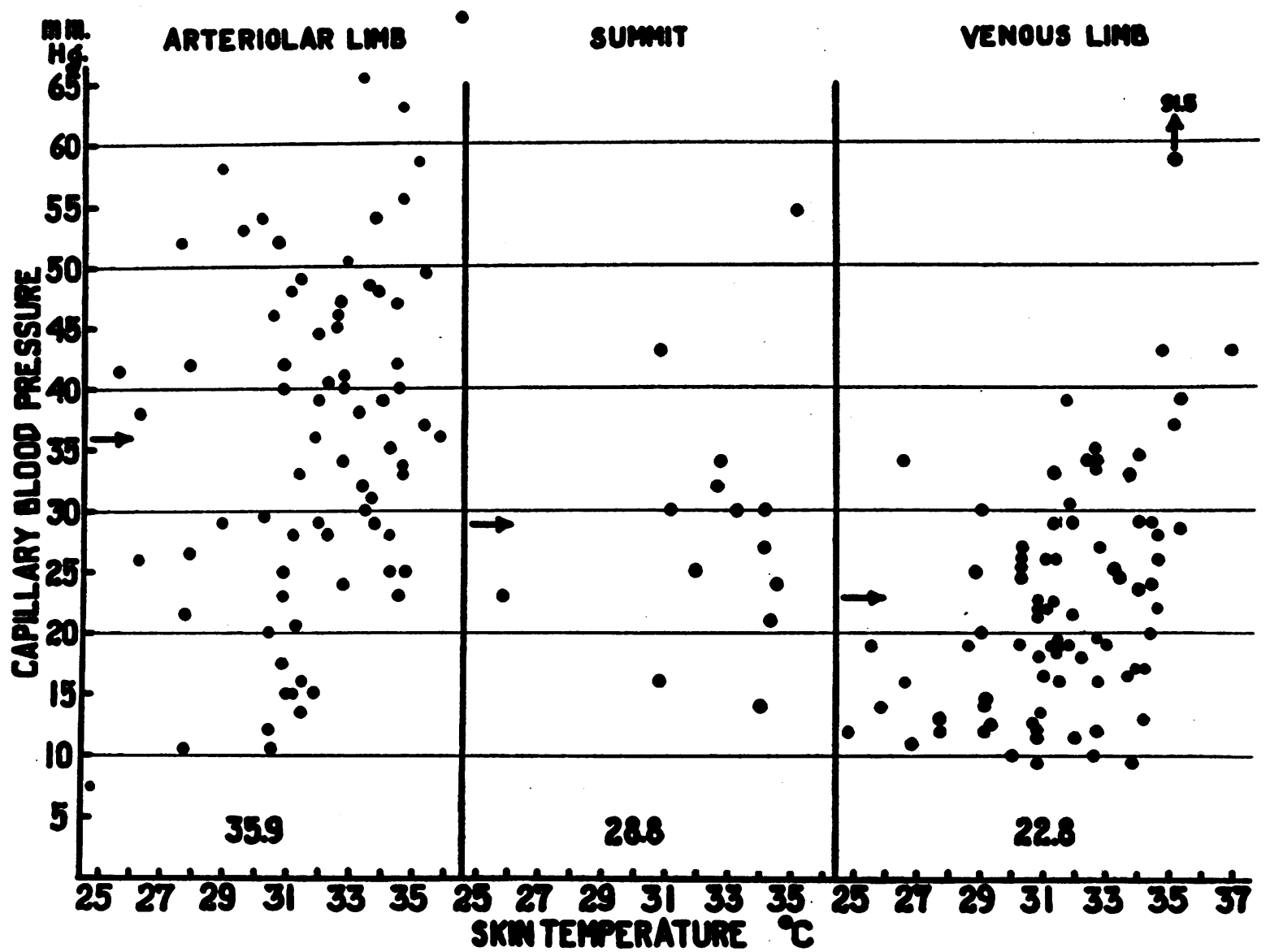

Fig. 3. Digital Capillary Blood Pressure in Different locations in the Capillary at Varying Levels of Digital Skin Temperature. Hypertensive Subjects

The pressures vary over the same range at both low and high temperatures.

obtained during the two states did not exceed -4 $\mathrm{mm}$. $\mathrm{Hg}$. to $+1.5 \mathrm{~mm}$. $\mathrm{Hg}$. (Table V).

Difficulty in piercing quickly normal sized capillaries during the early period of reactive hyperemia (transitory at best) led to studies on the more easily pierced abnormally large digital capillaries of patients with Raynaud's disease.

In the summits and venous limbs of 5 capillaries in 2 subjects with Raynaud's disease, the capillary blood pressure during reactive hyperemia differed from the resting values by only -1.5 $\mathrm{mm}$. $\mathrm{Hg}$ to $+5.5 \mathrm{~mm}$. $\mathrm{Hg}$ (average $2.5 \mathrm{~mm}$. $\mathrm{Hg}$ ), usually in the positive direction (Table VI). This maintained whether the reactive hyperemia involved the entire forearm or the digit alone.

After preganglionic sympathectomy of the upper extremity of the same 2 subjects, the observations were repeated with generally similar results ( Ta- ble VII). In the summits and venous limbs of 10 capillaries, the capillary blood pressure during reactive hyperemia differed from the resting values by $-11.0 \mathrm{~mm}$. $\mathrm{Hg}$ to $+4.5 \mathrm{~mm}$. $\mathrm{Hg}$ (average 4 $\mathrm{mm} . \mathrm{Hg}$ ) usually in a negative direction (Table VII). The occasional considerable difference was obtained when the determination was made quickly after onset of the hyperemia, when the preceding ischemia was of long duration (10 minutes rather than 5), and when the area of hyperemia was great (forearm rather than digit alone).

\section{Histamine acid phosphate $(1: 100)$ injected intradermally}

These experiments were few in number. During the erythema produced by the intradermal injection of histamine, considerable variation in digital capillary blood pressure still persisted in both 
TABLE III

Capillary blood pressure in normal and hypertensive subjects

\begin{tabular}{|c|c|c|c|c|c|c|c|c|c|c|c|c|}
\hline \multirow{3}{*}{. } & \multicolumn{4}{|c|}{ Arteriolar limb } & \multicolumn{4}{|c|}{ Summit } & \multicolumn{4}{|c|}{ Venous limb } \\
\hline & \multirow{2}{*}{$\begin{array}{c}\text { Num- } \\
\text { ber of } \\
\text { sub- } \\
\text { jects }\end{array}$} & \multirow{2}{*}{$\begin{array}{l}\text { Num- } \\
\text { ber of } \\
\text { capil- } \\
\text { laries }\end{array}$} & \multicolumn{2}{|c|}{ Capillary pressure } & \multirow{2}{*}{$\begin{array}{c}\text { Num- } \\
\text { ber of } \\
\text { sub- } \\
\text { jects }\end{array}$} & \multirow{2}{*}{$\begin{array}{l}\text { Num- } \\
\text { ber of } \\
\text { capil- } \\
\text { laries }\end{array}$} & \multicolumn{2}{|c|}{ Capillary pressure } & \multirow{2}{*}{$\begin{array}{c}\text { Num- } \\
\text { ber of } \\
\text { sub- } \\
\text { jects }\end{array}$} & \multirow{2}{*}{$\begin{array}{l}\text { Num- } \\
\text { ber of } \\
\text { capil- } \\
\text { laries }\end{array}$} & \multicolumn{2}{|c|}{ Capillary pressure } \\
\hline & & & Range & Average & & & Range & Average & & & Range & Average \\
\hline Normal ........... & 31 & 59 & $\begin{array}{r}m m . ~ \\
7 g \\
7.5 \text { to } 60\end{array}$ & $\begin{array}{c}\operatorname{mm} . H_{g} \\
30.6\end{array}$ & 12 & 14 & $\begin{array}{c}\mathrm{mm} . \mathrm{Hg}_{\mathrm{g}} \\
11 \text { to } 44\end{array}$ & $\begin{array}{c}\operatorname{mm} . \mathrm{H}_{\mathrm{g}} \\
29.5\end{array}$ & 42 & 84 & $\begin{array}{c}\mathrm{mm} . \mathrm{Hg}_{\mathrm{g}} \\
7.5 \text { to } 47\end{array}$ & $\begin{array}{c}\operatorname{mm} . H_{\ell} \\
21.9\end{array}$ \\
\hline Hypertensive . . . . . . & 29 & 75 & 7.5 to 70.5 & 35.9 & 10 & 14 & 14 to 54.5 & 28.8 & 35 & 83 & 9.5 to 43 & 22.8 \\
\hline
\end{tabular}

Most of the determinations were made at digital skin temperature between $30^{\circ} \mathrm{C}$. and $35^{\circ} \mathrm{C}$.

the arteriolar and venous limbs of normal and hypertensive subjects (Figure 6). In both groups, and for both locations in the capillary, the values did not exceed the upper limits obtained during moderate digital vasodilatation. However, the average capillary blood pressures in all locations of the capillary rose in both groups of subjects to exceed the average values obtained during resting conditions (Figure 6). These in- creases were greater in the venous limbs than in the arteriolar limbs. In the normal subjects, the average capillary blood pressure in the venous limb rose $8.8 \mathrm{~mm} . \mathrm{Hg}$, and in the arteriolar limb only $3.6 \mathrm{~mm}$. $\mathrm{Hg}$. In the hypertensive subjects, the increase in average capillary blood pressure in the venous limb was $18.7 \mathrm{~mm}$. $\mathrm{Hg}$, and in the arteriolar limb, $10.7 \mathrm{~mm}$. $\mathrm{Hg}$. Because of the greater increases in hypertensive subjects, the re-

TABLE IV

Gradient of blood pressure determined in the same capillary during a single experiment

\begin{tabular}{|c|c|c|c|c|c|c|c|c|c|}
\hline \multirow{2}{*}{$\begin{array}{l}\text { Subject } \\
\text { (Sex, } \\
\text { age) }\end{array}$} & \multirow{2}{*}{ Diagnosis } & \multirow{2}{*}{$\begin{array}{c}\text { Skin } \\
\text { tempera- } \\
\text { ture }\end{array}$} & \multirow{2}{*}{$\begin{array}{l}\text { Arterial } \\
\text { pressure }\end{array}$} & \multicolumn{5}{|c|}{ Capillary blood pressure } & \multirow{2}{*}{ Gradient } \\
\hline & & & & Arteriole & $\begin{array}{c}\text { Arteriolar } \\
\operatorname{limb}\end{array}$ & Summit & $\begin{array}{c}\text { Venous } \\
\text { limb }\end{array}$ & Venule & \\
\hline \multicolumn{10}{|c|}{ SUBJECTS WITH NORMAL ARTERIAL PRESSURE } \\
\hline $\begin{array}{l}\mathrm{E} . \mathrm{W} \\
(\mathbf{M}, 22)\end{array}$ & $\begin{array}{l}\text { Tetralogy of } \\
\text { Fallot }\end{array}$ & $\begin{array}{l}\circ C . \\
29.9\end{array}$ & $\begin{array}{c}m m . H_{g} \\
118 / 74\end{array}$ & $\underset{33}{m m_{B}} \mathrm{Hg}_{\mathrm{g}}$ & $\begin{array}{c}m m . H_{g} \\
21.5\end{array}$ & $m m . H_{g}$ & $m m . H_{g}$ & $m m . \mathrm{Hg}_{\mathbf{g}}$ & $\begin{array}{r}m m . H g \\
11.5\end{array}$ \\
\hline $\begin{array}{l}\text { A. G. } \\
(\mathbf{M}, 18)\end{array}$ & Normal & 30.2 & $130 / 72$ & & 12 & 11 & & & 1 \\
\hline$\underset{(\mathbf{M}, \mathbf{2 6})}{\mathbf{H} .}$ & $\begin{array}{c}\text { Convalescent } \\
\text { pneumonia }\end{array}$ & 32.9 & $144 / 56$ & & 26 & 25 & & & 1 \\
\hline $\begin{array}{l}\text { S. B. } \\
(\mathbf{M}, 37)\end{array}$ & $\begin{array}{l}\text { C. } \text { N. S. } \\
\text { syphilis }\end{array}$ & 33.6 & $112 / 64$ & & 34.5 & 22 & & & 12.5 \\
\hline C. J. J7) & Normal & 31.1 & $148 / 96$ & & 25 & & 20 & & 5 \\
\hline $\begin{array}{l}\text { C. J. } \\
(\mathbf{M}, 47)\end{array}$ & $\begin{array}{c}\text { Clubbed } \\
\text { fingers }\end{array}$ & 29.4 & $114 / 82$ & & 20 & & 27 & & -7 \\
\hline $\begin{array}{l}\text { W. H. } \\
(\mathbf{M}, 33)\end{array}$ & $\begin{array}{c}\text { Convalescent } \\
\text { pneumonia }\end{array}$ & 33.6 & $120 / 78$ & & 36 & & 14 & & 22 \\
\hline $\begin{array}{l}F . K \\
(F, 16)\end{array}$ & $\begin{array}{l}\text { Convalescent } \\
\text { nephritis }\end{array}$ & 33.4 & $138 / 98$ & & 57 & & 24 & & 33 \\
\hline$\underset{(\mathbf{M}, 41)}{\mathrm{J}}$ & & 32.4 & $126 / 96 ?$ & & & & 13 & 12.5 & 0.5 \\
\hline
\end{tabular}


TABLE IV-Continued

\begin{tabular}{|c|c|c|c|c|c|c|c|c|c|}
\hline \multirow{2}{*}{$\begin{array}{l}\text { Subject } \\
\text { (Sex. } \\
\text { age) }\end{array}$} & \multirow{2}{*}{ Diagnosis } & \multirow{2}{*}{$\begin{array}{c}\text { Skin } \\
\text { tempera- } \\
\text { ture }\end{array}$} & \multirow{2}{*}{$\begin{array}{l}\text { Arterial } \\
\text { pressure }\end{array}$} & \multicolumn{5}{|c|}{ Capillary blood pressure } & \multirow{2}{*}{ Gradient } \\
\hline & & & & Arteriole & $\begin{array}{c}\text { Arteriolar } \\
\text { limb }\end{array}$ & Summit & $\begin{array}{c}\text { Venous } \\
\text { limb }\end{array}$ & Venule & \\
\hline \multicolumn{10}{|c|}{ HYPERTENSIVE SUBJECTS } \\
\hline $\begin{array}{l}\text { E. B. } \\
(\mathbf{F}, 35)\end{array}$ & $\begin{array}{l}\text { Malignant } \\
\text { hypertension }\end{array}$ & $\begin{array}{l}{ }^{\circ} \mathrm{C} . \\
34.4\end{array}$ & $\begin{array}{c}m m . H_{g} \\
230 / 170\end{array}$ & $\underset{58}{m m . H g}$ & $\begin{array}{c}m m . H g \\
47\end{array}$ & $m m . \mathrm{Hg}$ & $m m . \mathrm{Hg}$ & $m m . H g$ & $\begin{array}{c}m m . H \\
11\end{array}$ \\
\hline $\begin{array}{l}\text { T. R. R. } \\
(\mathrm{F}, 38)\end{array}$ & $\begin{array}{l}\text { Essential } \\
\text { hypertension }\end{array}$ & 33.8 & $172 / 130$ & 5 & 11 & & & & -6 \\
\hline$\underset{(F, 28)}{\text { E. } S_{.}}$ & $\begin{array}{l}\text { Essential } \\
\text { hypertension }\end{array}$ & 34.6 & $182 / 118$ & 74 & 33.5 & & & & 40.5 \\
\hline $\begin{array}{l}\text { C. B. } \\
(\mathbf{M}, 35)\end{array}$ & $\begin{array}{l}\text { Essential } \\
\text { hypertension }\end{array}$ & 35.1 & $222 / 148$ & 76 & & 54.5 & & & 21.5 \\
\hline$\underset{(M, 35)}{H . ~ B .}$ & $\begin{array}{l}\text { Essential } \\
\text { hypertension }\end{array}$ & 34.0 & $174 / 130$ & 41 & & & 34.5 & & 6.5 \\
\hline$\underset{(\mathrm{F}, \mathbf{5 0})}{\mathrm{K}}$ & $\begin{array}{l}\text { Hypertension } \\
\text { telangectases }\end{array}$ & 30.8 & $186 / 96$ & & 25 & 16 & & & 9 \\
\hline $\begin{array}{l}\text { V. M. } \\
(\mathrm{F}, 29)\end{array}$ & $\begin{array}{l}\text { Essential } \\
\text { hypertension }\end{array}$ & 31.1 & $164 / 120$ & & 28 & $30^{\circ}$ & & & -2 \\
\hline $\begin{array}{l}\text { E. S. } \\
(\mathrm{F}, 28)\end{array}$ & $\begin{array}{l}\text { Essential } \\
\text { hypertension }\end{array}$ & 34.2 & $166 / 112$ & & 25 & 39 & & & -14 \\
\hline$\underset{(\mathbf{M}, 41)}{\mathrm{J}}$ & $\begin{array}{c}\text { Subarachnoid } \\
\text { hemorrhage }\end{array}$ & 31.4 & $182 / 106$ & & 16 & 20.5 & & & -4.5 \\
\hline $\begin{array}{l}\text { H. B. } \\
(\mathrm{F}, 29)\end{array}$ & $\begin{array}{l}\text { Essential } \\
\text { hypertension }\end{array}$ & 35.3 & $154 / 112$ & & 37 & & 28.5 & & 8.5 \\
\hline $\begin{array}{l}\text { H. B. } \\
(\mathrm{F}, 29)\end{array}$ & $\begin{array}{l}\text { Essential } \\
\text { hypertension }\end{array}$ & 34.6 & $152 / 106$ & & 33 & & 26 & & 7 \\
\hline $\begin{array}{l}\text { E. B. } \\
(\mathbf{F}, 35)\end{array}$ & $\begin{array}{l}\text { Malignant } \\
\text { hypertension }\end{array}$ & 32.8 & $216 / 160$ & & 50.5 & & 27 & & 23.5 \\
\hline $\begin{array}{l}\text { F. L. } \\
(\mathbf{F}, \mathbf{3 3})\end{array}$ & $\begin{array}{l}\text { Essential } \\
\text { hypertension }\end{array}$ & 32.7 & $174 / 116$ & & 41 & & 12 & & 29 \\
\hline $\begin{array}{l}F . L . \\
(\mathbf{F}, 33)\end{array}$ & $\begin{array}{l}\text { Essential } \\
\text { hypertension }\end{array}$ & 32.7 & $174 / 116$ & & 34 & & 16 & & 18 \\
\hline $\begin{array}{l}\text { V. M. } \\
(\mathrm{F}, 29)\end{array}$ & $\begin{array}{l}\text { Essential } \\
\text { hypertension }\end{array}$ & $?$ & $196 / 124$ & & 17.5 & & 9.5 & & 8 \\
\hline $\begin{array}{c}\text { C. } \\
(\mathbf{M}, 29)\end{array}$ & $\begin{array}{l}\text { Essential } \\
\text { hypertension }\end{array}$ & 30.2 & $156 / 106$ & & 29 & & 19 & & 10 \\
\hline $\begin{array}{l}\text { E. S. } \\
(\mathrm{F}, 28)\end{array}$ & $\begin{array}{l}\text { Essential } \\
\text { hypertension }\end{array}$ & 34.6 & $182 / 118$ & . & 33.5 & & 28 & & 5.5 \\
\hline $\begin{array}{l}F . L . \\
(F, 33)\end{array}$ & $\begin{array}{l}\text { Essential } \\
\text { hypertension }\end{array}$ & 34.5 & $170 / 120$ & & & 24 & 22 & & 2 \\
\hline $\begin{array}{l}\text { V. M. } \\
(\mathbf{F}, 29)\end{array}$ & $\begin{array}{l}\text { Essential } \\
\text { hypertension }\end{array}$ & 31.1 & $164 / 120$ & & & 30 & 26 & & 4 \\
\hline$\underset{(\mathbf{M}, \mathbf{3 7})}{\mathrm{R} .}$ & $\begin{array}{l}\text { Essential } \\
\text { hypertension }\end{array}$ & 33.9 & $204 / 142$ & & & & 16 & 14 & 2 \\
\hline $\begin{array}{l}\text { V. M. } \\
(\mathrm{F}, 29)\end{array}$ & $\begin{array}{l}\text { Essential } \\
\text { hypertension }\end{array}$ & 24.8 & $154 / 106$ & & & & 12 & 11.5 & 0.5 \\
\hline
\end{tabular}




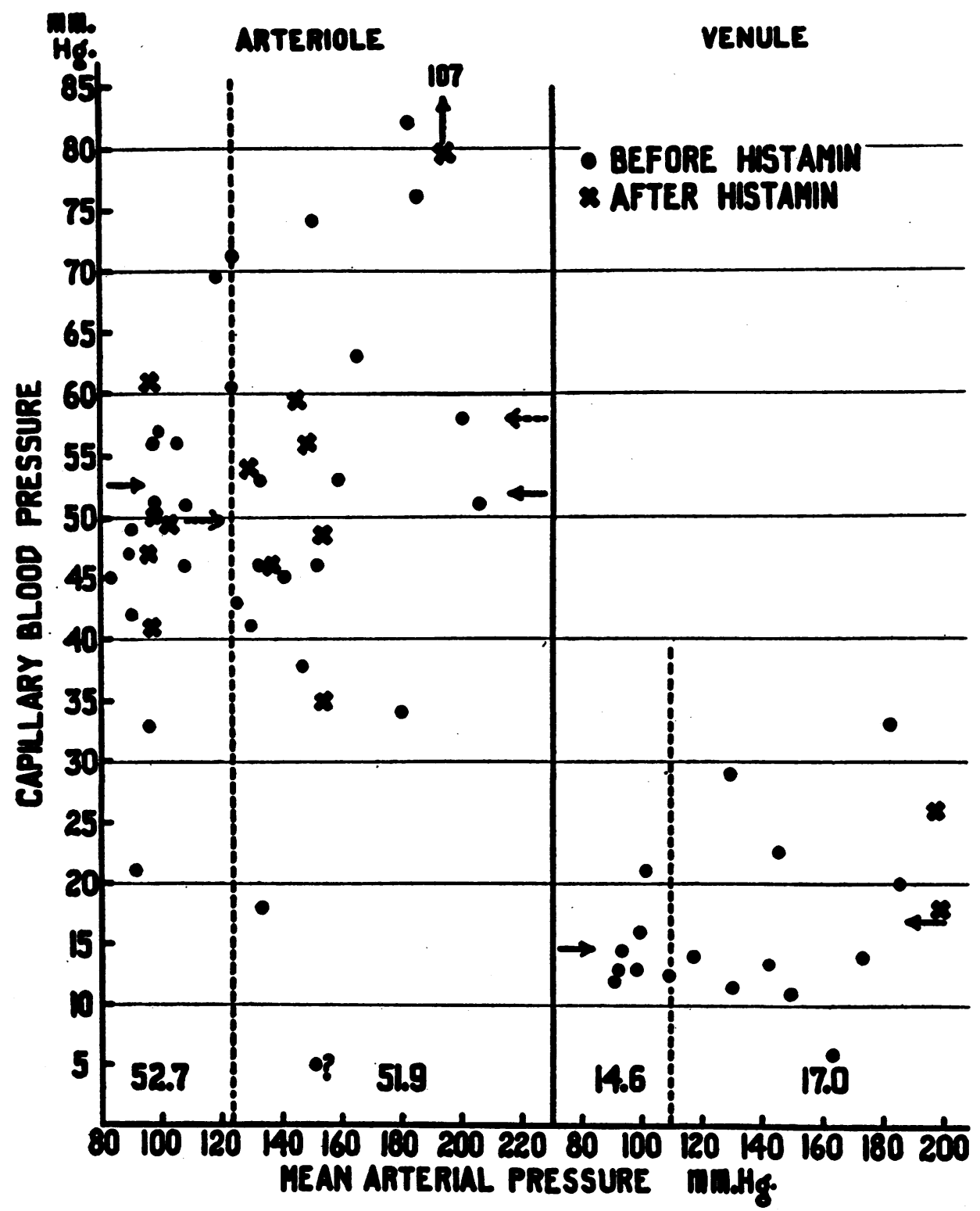

Fig. 4. The Blood Pressure in "Arterioles". and "Venules" during the Resting State and during Histamine Flare in Normal and Hypertensive Subjects

The solid horizontal arrows and the numbers above the abscissa line indicate average pressures during the resting state; the dotted arrows, average values during histamine flare. "Arteriole" and "venule" pressures in normal and hypertensive subjects vary over the same range, both during the resting state and during local hyperemia from histamine.

\begin{tabular}{|c|c|c|c|c|c|c|c|c|}
\hline & \multicolumn{4}{|c|}{ "Arterioles" } & \multicolumn{4}{|c|}{ "Venules" } \\
\hline & \multirow{2}{*}{ Number of } & \multirow{2}{*}{$\begin{array}{l}\text { Number of } \\
\text { capillaries }\end{array}$} & \multicolumn{2}{|c|}{ Pressure } & \multirow{2}{*}{$\begin{array}{l}\text { Number of } \\
\text { subjects }\end{array}$} & \multirow{2}{*}{$\begin{array}{l}\text { Number of } \\
\text { capillaries }\end{array}$} & \multicolumn{2}{|c|}{ Pressure } \\
\hline & & & Range & Average & & & Range & Average \\
\hline 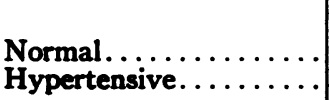 & $\begin{array}{l}11 \\
13\end{array}$ & $\begin{array}{l}15 \\
17\end{array}$ & $\begin{array}{l}m m . H g \\
21 \text { to } 71 \\
18 \text { to } 82\end{array}$ & $\begin{array}{c}\operatorname{mm} . \mathrm{HE} \\
52.7 \\
51.9\end{array}$ & $\begin{array}{l}7 \\
9\end{array}$ & $\begin{array}{r}7 \\
10\end{array}$ & $\begin{array}{r}m m . ~ \\
H_{g} \\
12 \text { to } 21 \\
6 \text { to } 33\end{array}$ & $\begin{array}{c}\operatorname{ms} . \mathrm{B} \\
14.6 \\
17.0\end{array}$ \\
\hline
\end{tabular}




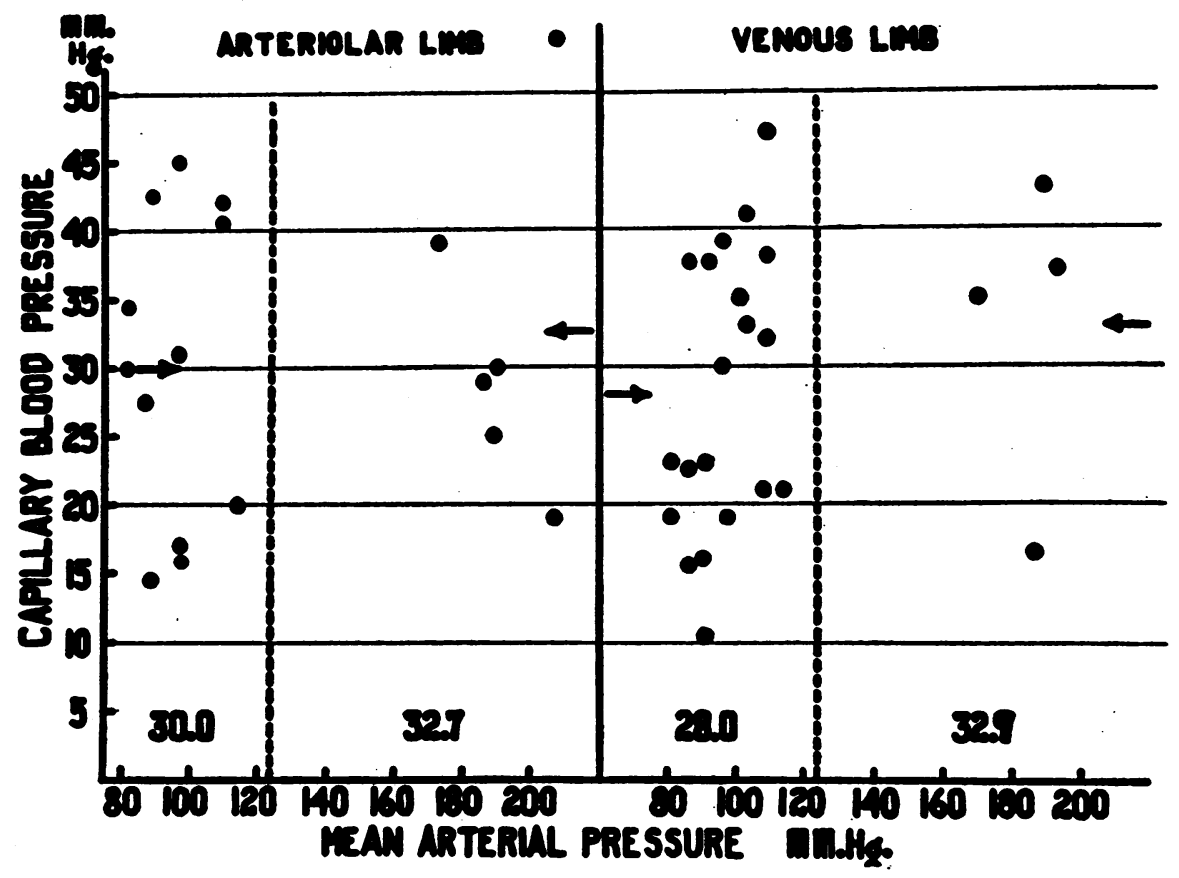

Fig. 5. Digital Capillary Blood Pressure Measured during Reflex Vasodilatation in Normal and Hypertensive SUbJects

Capillary blood pressure in normal subjects:

12 arteriolar limbs of 7 subjects $-14.5 \mathrm{~mm}$. $\mathrm{Hg}$ to $45 \mathrm{~mm}$. $\mathrm{Hg}$, average $30 \mathrm{~mm}$. $\mathrm{Hg}$ 20 venous limbs of 9 subjects $-10.5 \mathrm{~mm}$. $\mathrm{Hg}$ to $47 \mathrm{~mm}$. $\mathrm{Hg}$, average $28 \mathrm{~mm}$. $\mathrm{Hg}$

Capillary blood pressure in hypertensive subjects:

6 arteriolar limbs of 5 subjects- $19 \mathrm{~mm}$. $\mathrm{Hg}$ to $54 \mathrm{~mm}$. $\mathrm{Hg}$, average $32.7 \mathrm{~mm}$. $\mathrm{Hg}$ 4 venous limbs of 3 subjects- $16.5 \mathrm{~mm}$. $\mathrm{Hg}$ to $43 \mathrm{~mm}$. $\mathrm{Hg}$, average $32.9 \mathrm{~mm} . \mathrm{Hg}$

In both normal and hypertensive subjects the pressures are similar in both limbs of the capillary.

TABLE V

The effect of reactive hyperemia on the capillary blood pressure. Normal sised capillaries. Innervation intact

\begin{tabular}{|c|c|c|c|c|c|c|c|c|c|c|c|c|}
\hline \multirow{3}{*}{$\begin{array}{l}\text { Sub- } \\
\text { ject } \\
\text { (Sex. } \\
\text { age) }\end{array}$} & \multirow{3}{*}{ Diagnosis } & \multicolumn{4}{|c|}{ Resting state } & \multicolumn{6}{|c|}{ Reactive hyperemia } & \multirow{3}{*}{$\begin{array}{l}\text { Location in } \\
\text { capillary } \\
\text { where blood } \\
\text { pressure } \\
\text { was } \\
\text { determined }\end{array}$} \\
\hline & & \multirow{2}{*}{$\begin{array}{l}\text { Skin } \\
\text { tem- } \\
\text { pera- } \\
\text { ture }\end{array}$} & \multicolumn{2}{|c|}{$\begin{array}{l}\text { Arterial } \\
\text { pressure }\end{array}$} & \multirow[b]{2}{*}{$\begin{array}{l}\text { Capillary } \\
\text { blood } \\
\text { pressure }\end{array}$} & \multirow{2}{*}{$\begin{array}{l}\text { Skin } \\
\text { tem- } \\
\text { pera- } \\
\text { ture }\end{array}$} & \multicolumn{2}{|c|}{$\begin{array}{l}\text { Arterial } \\
\text { pressure }\end{array}$} & \multicolumn{2}{|c|}{$\begin{array}{l}\text { Capillary blood } \\
\text { pressure }\end{array}$} & \multirow{2}{*}{$\begin{array}{l}\text { Duration of } \\
\text { and area of } \\
\text { ischemia } \\
\text { preceding the } \\
\text { hyperemia }\end{array}$} & \\
\hline & & & Reading & "Mean" & & & Reading & "Mean" & Reading & $\begin{array}{c}\text { Time of } \\
\text { reading } \\
\text { after on- } \\
\text { set of } \\
\text { hyperemia }\end{array}$ & & \\
\hline$\underset{(\mathrm{F}, \mathbf{3 1})}{\mathrm{H}}$ & $\begin{array}{l}\text { Eesential } \\
\text { hypertension }\end{array}$ & $\begin{array}{l}{ }^{\circ} \mathrm{C} . \\
34.1\end{array}$ & \begin{tabular}{|l|}
$m m . B g$ \\
$166 / 116$
\end{tabular} & $\begin{array}{c}m m . B g \\
141\end{array}$ & $\begin{array}{c}m m . H z \\
29.5\end{array}$ & ${ }^{\circ} \mathrm{C} .0$ & \begin{tabular}{|l}
$m m . H g$ \\
$160 / 114$
\end{tabular} & $\underset{137}{m m . B 8}$ & ${ }_{31}^{m m_{2} H_{2}}$ & $\begin{array}{l}\text { seconds } \\
23\end{array}$ & 5 minutes, digit & Summit \\
\hline$\underset{\left(F, \frac{L}{35}\right)}{\text { F. }}$ & $\begin{array}{l}\text { Eesential } \\
\text { hypertension }\end{array}$ & 35.0 & $166 / 122$ & 144 & 23 & 35.0 & $166 / 122$ & 144 & 19 & 32 & 5 minutes, digit & Arteriolar limb \\
\hline (F. S. & $\begin{array}{l}\text { Eesential } \\
\text { hypertension }\end{array}$ & 35.0 & $164 / 110$ & 137 & 22.5 & $\begin{array}{l}33.7 \\
34.1\end{array}$ & \begin{tabular}{|l|}
$164 / 110$ \\
$168 / 112$
\end{tabular} & $\begin{array}{l}137 \\
140\end{array}$ & $\begin{array}{l}23 \\
21\end{array}$ & $\begin{array}{l}24 \\
24\end{array}$ & $\begin{array}{l}5 \text { minutes, digit } \\
5 \text { minutes, digit }\end{array}$ & $\begin{array}{l}\text { Venous } \operatorname{limb} \\
\text { Venous } \operatorname{limb}\end{array}$ \\
\hline$\underset{(\mathrm{F}, \mathrm{M}}{\mathrm{M}} \mathbf{\mathrm { E }}$ & Normal & 33.5 & $116 / 78$ & 97 & 26.5 & 32.7 & $118 / 80$ & 99 & $\begin{array}{l}22.5 \text { to } \\
25.0\end{array}$ & 55 & 5 minutes, digit & Summit \\
\hline
\end{tabular}


TABLE VI

The effect of reactive hyperemia on the capillary blood pressure. Abnormally large capillaries. Innervation intact

\begin{tabular}{|c|c|c|c|c|c|c|c|c|c|c|c|c|}
\hline \multirow{3}{*}{$\begin{array}{l}\text { Sub- } \\
\text { ject } \\
\text { (Sex. } \\
\text { age) }\end{array}$} & \multirow{3}{*}{ Diagnosis } & \multicolumn{4}{|c|}{ Resting state } & \multicolumn{6}{|c|}{ Reactive hyperemia } & \multirow{3}{*}{$\begin{array}{l}\text { Location in } \\
\text { capillary where } \\
\text { blood pressure } \\
\text { was determined }\end{array}$} \\
\hline & & \multirow{2}{*}{$\begin{array}{l}\text { Skin } \\
\text { tem- } \\
\text { pera- } \\
\text { ture }\end{array}$} & \multicolumn{2}{|c|}{$\begin{array}{l}\text { Arterial } \\
\text { pressure }\end{array}$} & \multirow{2}{*}{$\begin{array}{l}\text { Capil- } \\
\text { lary } \\
\text { blood } \\
\text { pres- } \\
\text { sure }\end{array}$} & \multirow{2}{*}{$\begin{array}{l}\text { Skin } \\
\text { tem- } \\
\text { pera- } \\
\text { ture }\end{array}$} & \multicolumn{2}{|c|}{$\begin{array}{l}\text { Arterial } \\
\text { pressure }\end{array}$} & \multicolumn{2}{|c|}{$\begin{array}{l}\text { Capillary blood } \\
\text { pressure }\end{array}$} & \multirow{2}{*}{$\begin{array}{l}\text { Duration of } \\
\text { and area of } \\
\text { ischemia } \\
\text { preceding the } \\
\text { hyperemia }\end{array}$} & \\
\hline & & & Reading & "Mean" & & & Reading & "Mean" & Reading & $\begin{array}{l}\text { Time of } \\
\text { reading } \\
\text { after on- } \\
\text { set of } \\
\text { hyperemia }\end{array}$ & & \\
\hline C. & $\begin{array}{c}\text { Raynaud's } \\
\text { disease }\end{array}$ & $\begin{array}{l}{ }^{\circ} \mathrm{C} . \\
26.5 \\
32.7 \\
33.6\end{array}$ & \begin{tabular}{|c|}
$\mathrm{mm} . \mathrm{Hg}$ \\
$132 / 88$ \\
$120 / 80$ \\
$120 / 86$
\end{tabular} & 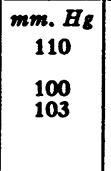 & $\begin{array}{l}\mathrm{mm} . \mathrm{Hg} \\
22.5 \\
28 \\
30.5\end{array}$ & $\begin{array}{l}{ }^{\circ} C . \\
28.6 \\
30.0 \\
30.3 \\
33.6 \\
32.8 \\
32.2\end{array}$ & \begin{tabular}{|c|}
$\mathrm{mm} . \mathrm{Hg}$ \\
$132 / 88$ \\
$132 / 88$ \\
$120 / 80$ \\
$120 / 86$ \\
$120 / 82$ \\
$126 / 82$
\end{tabular} & 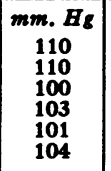 & \begin{tabular}{|c|}
$m m . ~ H g$ \\
24 \\
26 \\
33 \\
36 \\
28 \\
32 \\
\end{tabular} & $\begin{array}{c}\text { seconds } \\
35 \\
30 \\
45 \\
30 \\
25 \\
25\end{array}$ & $\begin{array}{l}5 \text { minutes, digit } \\
5 \text { minutes, forearm } \\
5 \text { minutes, digit } \\
5 \text { minutes, digit } \\
5 \text { minutes, forearm } \\
5 \text { minutes, digit }\end{array}$ & $\begin{array}{l}\text { Venous limb } \\
\text { Venous limb } \\
\text { Summit } \\
\text { Summit }\end{array}$ \\
\hline$\underset{(\mathbf{M}, \mathbf{3 2})}{\mathbf{F}}$ & $\begin{array}{c}\text { Raynaud's } \\
\text { disease }\end{array}$ & $\begin{array}{l}31.1 \\
32.3\end{array}$ & $\begin{array}{l}120 / 82 \\
125 / 86\end{array}$ & $\begin{array}{l}101 \\
106\end{array}$ & $\begin{array}{l}19.5 \\
19.5\end{array}$ & $\begin{array}{l}32.6 \\
32.3\end{array}$ & $\begin{array}{l}130 / 84 \\
125 / 86\end{array}$ & $\begin{array}{l}107 \\
106\end{array}$ & $\begin{array}{l}20 \\
21.5\end{array}$ & 20 & $\begin{array}{l}5 \text { minutes, forearm } \\
5 \text { minutes, forearm }\end{array}$ & $\begin{array}{l}\text { Summit, venous } \\
\text { limb (different } \\
\text { locations) } \\
\text { Venous limb }\end{array}$ \\
\hline
\end{tabular}

sultant average capillary blood pressures in both the arteriolar and venous limbs were higher in hypertensive than in normal subjects: arteriolar limb-normal $34.2 \mathrm{~mm}$. $\mathrm{Hg}$, hypertensive 46.6 $\mathrm{mm}$. $\mathrm{Hg}$; venous limb-normal $30.7 \mathrm{~mm}$. $\mathrm{Hg}$, hypertensive $41.5 \mathrm{~mm}$. $\mathrm{Hg}$.

Due to the disproportionately greater increases in venous limb pressure than in the arteriolar limb pressure, the gradient of fall of pressure from arteriolar limb to venous limb was less steep during the erythema produced by histamine than during the usual moderate digital vasodilatation. In the few normal subjects studied, this gradient was $3.5 \mathrm{~mm}$. $\mathrm{Hg}$ and in the hypertensive subjects, $5.1 \mathrm{~mm}$. Hg (Figure 6). The local blood flow during this erythema is believed to be much increased. During the histamine flare, the arteriole blood pressure in both normal and hypertensive subjects was not significantly altered from that during moderate digital vasodilatation alone (Figure 4). In the normal subjects, the average arteriole blood pressure during the resting state was

TABLE VII

The effect of reactive hyperemia on the capillary blood pressure. Abnormally large capillaries. Sympathectomized extremity

\begin{tabular}{|c|c|c|c|c|c|c|c|c|c|c|c|c|}
\hline \multirow{3}{*}{$\begin{array}{l}\text { Sub- } \\
\text { ject } \\
\text { (Sex, } \\
\text { age) }\end{array}$} & \multirow{3}{*}{ Diagnosis } & \multicolumn{4}{|c|}{ Resting state } & \multicolumn{6}{|c|}{ Reactive hyperemia } & \multirow{3}{*}{$\begin{array}{l}\text { Location in } \\
\text { capillary where } \\
\text { blood pressure } \\
\text { was determined }\end{array}$} \\
\hline & & \multirow{2}{*}{$\begin{array}{l}\text { Skin } \\
\text { tem- } \\
\text { pera- } \\
\text { ture }\end{array}$} & \multicolumn{2}{|c|}{$\begin{array}{l}\text { Arterial } \\
\text { pressure }\end{array}$} & \multirow{2}{*}{$\begin{array}{l}\text { Capil- } \\
\text { lary } \\
\text { blood } \\
\text { pres- } \\
\text { sure }\end{array}$} & \multirow{2}{*}{$\begin{array}{l}\text { Skin } \\
\text { tem- } \\
\text { pera- } \\
\text { ture }\end{array}$} & \multicolumn{2}{|c|}{$\begin{array}{l}\text { Arterial } \\
\text { pressure }\end{array}$} & \multicolumn{2}{|c|}{$\begin{array}{l}\text { Capillary blood } \\
\text { pressure }\end{array}$} & \multirow{2}{*}{$\begin{array}{l}\text { Duration of } \\
\text { and area of } \\
\text { ischemia } \\
\text { preceding the } \\
\text { hyperemia }\end{array}$} & \\
\hline & & & Reading & "Mean" & & & Reading & "Mean" & Reading & $\begin{array}{c}\text { after } \\
\text { onset of } \\
\text { hyperemia }\end{array}$ & & \\
\hline $\begin{array}{l}\text { C. M. M. } \\
(\mathbf{F}, 29)\end{array}$ & $\begin{array}{c}\text { Raynaud's } \\
\text { disease } \\
\text { (post } \\
\text { sympa- } \\
\text { thectomy) }\end{array}$ & $\begin{array}{l}{ }^{\circ} \mathrm{C} . \\
30.7 \\
32.3 \\
32.4\end{array}$ & $\begin{array}{c}\operatorname{mm} . H_{g} \\
114 / 68 \\
116 / 68 \\
126 / 86 \\
122 / 82\end{array}$ & $\begin{array}{c}\text { mm. } H_{g} \\
91 \\
92 \\
106 \\
102\end{array}$ & \begin{tabular}{|c|}
$\operatorname{mm} . H g$ \\
27 \\
22.5 \\
29.5 \\
\\
26
\end{tabular} & \begin{tabular}{l|}
$\circ C$. \\
30.7 \\
32.6 \\
32.4 \\
32.7 \\
33.8 \\
33.8
\end{tabular} & $\begin{array}{c}m m . H g \\
114 / 68 \\
116 / 68 \\
126 / 86 \\
128 / 86 \\
122 / 82 \\
120 / 78\end{array}$ & $\begin{array}{c}\operatorname{mm} . H_{\mathbf{g}} \\
91 \\
92 \\
106 \\
107 \\
102 \\
99\end{array}$ & \begin{tabular}{|l|}
$\operatorname{mm} . \mathrm{Hg}$ \\
19 \\
27 \\
22.5 \\
24.5 \\
19 \\
22
\end{tabular} & $\begin{array}{c}\text { seconds } \\
35 \\
35 \\
17 \\
27 \\
15 \\
42\end{array}$ & \begin{tabular}{|l|}
5 minutes, digit \\
5 minutes, digit \\
5 minutes, digit \\
5 minutes, forearm \\
10 minutes, digit \\
10 minutes, digit
\end{tabular} & $\begin{array}{l}\text { Summit-flow } \\
\text { seemed more slow } \\
\text { Venous limb } \\
\text { Venous limb }\end{array}$ \\
\hline$\underset{(\mathbf{M}, \mathbf{3 2})}{\mathbf{F}}$ & $\begin{array}{l}\text { Raynaud's } \\
\text { disease } \\
\text { (after } \\
\text { 8ympa- } \\
\text { thectomy) }\end{array}$ & $\begin{array}{l}31.4 \\
30.4 \\
31.4 \\
31.4 \\
32.8 \\
30.8 \\
29.4\end{array}$ & $\begin{array}{l}114 / 70 \\
114 / 74 \\
114 / 74 \\
122 / 86 \\
117 / 76 \\
128 / 88 \\
126 / 82\end{array}$ & $\begin{array}{r}92 \\
94 \\
94 \\
94 \\
104 \\
97 \\
108 \\
104\end{array}$ & $\begin{array}{l}15 \\
14 \\
13.5 \\
28 \\
17.5 \\
21-28 \\
18.5\end{array}$ & $\begin{array}{l}31.4 \\
32.4 \\
31.9 \\
31.9 \\
31.4 \\
32.2 \\
32.3 \\
29.4\end{array}$ & $\begin{array}{l}114 / 74 \\
126 / 86 \\
130 / 94 \\
130 / 94 \\
116 / 74 \\
124 / 86 \\
128 / 88 \\
126 / 82\end{array}$ & $\begin{array}{r}94 \\
106 \\
112 \\
112 \\
95 \\
105 \\
108 \\
104\end{array}$ & $\begin{array}{l}12.5 \\
15 \\
15 \\
14 \\
17 \\
14 \\
20.5 \\
18.5\end{array}$ & $\begin{array}{l}20 \\
35 \\
25 \\
30 \\
20 \\
30 \\
22 \\
72\end{array}$ & \begin{tabular}{|l|}
5 minutes, forearm \\
5 minutes, digit \\
5 minutes, digit \\
5 minutes, digit \\
10 minutes, digit \\
5 minutes, digit \\
10 minutes, digit \\
10 minutes, digit
\end{tabular} & $\begin{array}{l}\text { Summit } \\
\text { Summit } \\
\text { Venous limb } \\
\text { Summit } \\
\text { Venous limb } \\
\text { Venous limb } \\
\text { Summit }\end{array}$ \\
\hline
\end{tabular}


$52.7 \mathrm{~mm}$. $\mathrm{Hg}$, during the erythema $49.9 \mathrm{~mm}$. $\mathrm{Hg}$, and in the hypertensive subjects, $51.9 \mathrm{~mm}$. $\mathrm{Hg}$ and $58 \mathrm{~mm} . \mathrm{Hg}$, respectively.

During a single experiment, the capillary blood pressure in the same location in a given capillary was measured, both before and after the production of a histamine-flare. In 3 normal subjects and 6 hypertensive patients, approximately equal changes were induced in the capillary blood pressure by the histamine-flare (Figure 7). No correlation existed between the extent of the change in capillary blood pressure and the mean arterial pressure.

\section{Relation of capillary blood pressure to mean brachial arterial pressure}

Neither in normal nor in hypertensive subjects was there any correlation between the digital capillary blood pressure and the systolic, diastolic, or mean arterial pressures. This maintained for the range as well as for average values, and for pressures in both the arteriolar (Figure 8 ) and venous limbs (Figure 9). The lack of correlation was emphasized by the finding of almost equal digital capillary blood pressures in 2 patients. In one, the brachial arterial pressure was unobtainable (aneurysm), in the other the mean arterial pressure was

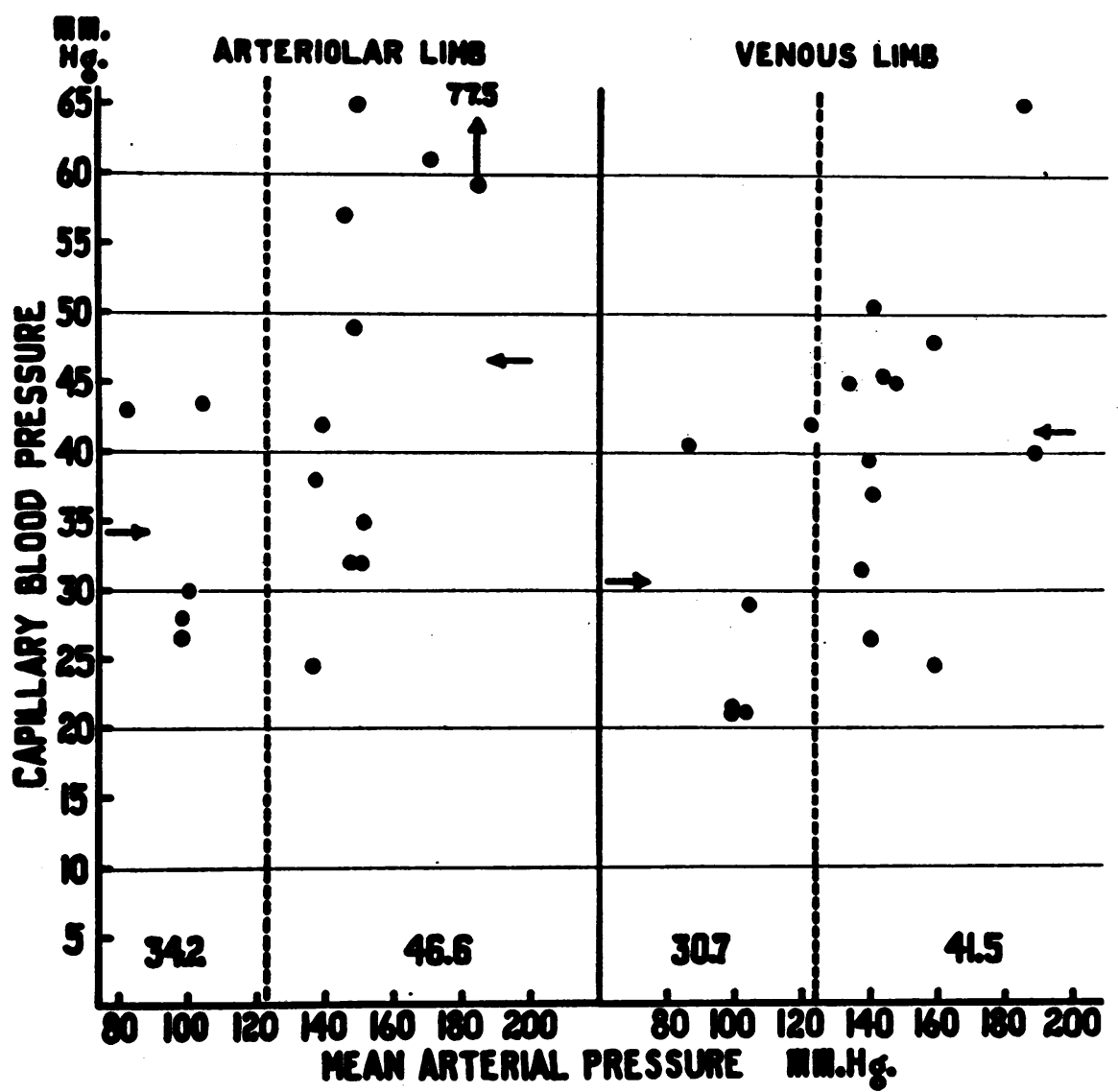

Fig. 6. Digital Capillary Blood Pressure Measured during local Hyperemia of Histamine in Normal and Hypertensive Subjects

Capillary blood pressure in normal subjects:

5 arteriolar limbs of 4 subjects $-26.5 \mathrm{~mm}$. $\mathrm{Hg}$ to $43.5 \mathrm{~mm}$. $\mathrm{Hg}$, average $34.2 \mathrm{~mm}$. $\mathrm{Hg}$

5 venous limbs of 5 subjects- $11 \mathrm{~mm}$. $\mathrm{Hg}$ to $42 \mathrm{~mm}$. $\mathrm{Hg}$, average $30.7 \mathrm{~mm}$. $\mathrm{Hg}$

Capillary blood pressure in hypertensive subjects:

11 arteriolar limbs of 7 subjects $-24.5 \mathrm{~mm}$. $\mathrm{Hg}$ to $77.5 \mathrm{~mm}$. $\mathrm{Hg}$, average $46.6 \mathrm{~mm}$. $\mathrm{Hg}$

12 venous limbs of 6 subjects-24.5 mm. $\mathrm{Hg}$ to $65 \mathrm{~mm}$. $\mathrm{Hg}$, average $41.5 \mathrm{~mm}$. $\mathrm{Hg}$

In both arteriolar and venous limbs capillary blood pressure is higher in hypertensive than in normal subjects. 


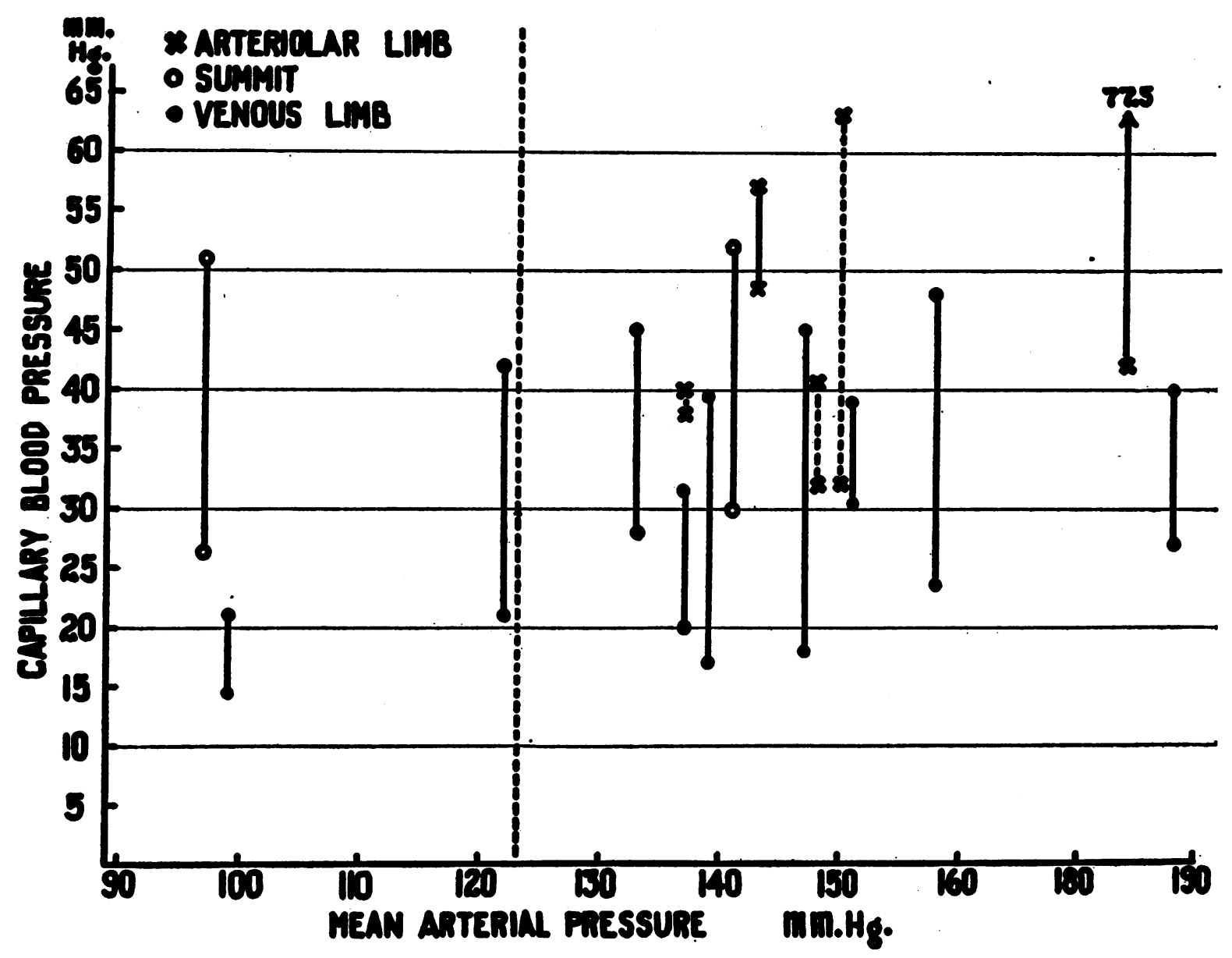

Fig. 7. Digital Capillary Blood Pressure Measured in the Same Capillary Before and During a Local Histamine Flare in Normal and Hypertensive Subjects

Increases in pressure in corresponding locations of the capillary seem as great in normal as in hypertensive subjects.

$201 \mathrm{~mm}$. Hg. Lack of correlation between digital capillary blood pressure and arterial pressure persisted during the action of the above described digital vasoconstrictions and vasodilatations.

In 4 hypertensive patients, no significant differences were noted between the capillary blood pressures determined during the hypertensive state and those obtained when the arterial pressure had returned to normal (Table VIII). Reduction in arterial pressure occurred spontaneously in 2 patients, accompanied unilateral nephrectomy in one, and in the fourth, followed bilateral subdiaphragmatic splanchnicectomy and lumbar ganglionectomy (9). Although these determinations of capillary blood pressure were not made in the same capillary, nor in the same location in the capillaries at the two levels of arterial pressure, the conditions were otherwise kept as nearly similar as possible.

While under observation, a moderately hypertensive patient developed local arterial disease which obliterated the arterial pulsations in the left upper extremity, thereby making indirect determinations of arterial pressure impossible. In the contralateral right arm, the arterial pressure remained moderately elevated. With the circulation to each upper extremity in moderate vasodilatation, the digital capillary blood pressure (determined largely in venous limbs) was almost identical on the two sides (Table VIII).

\section{DISCUSSION}

These observations were made on capillaries in the nail-folds of the fingers. The conclusions de- 
rived therefrom are limited to this single area and are not to be applied to capillaries in other regions of the body or to the circulation as a whole. In other areas, there may not be a duplication of the peculiarities of anatomic structure (10) (arteriolevenule anastomoses), or of labile physiologic reactivity found in the vascular system of the digits. To draw generalized conclusions from data obtained in this single, specialized area does not seem justifiable. It is to be understood that the following discussion pertains to one area alone, the nail-folds of the fingers.
In both normal and hypertensive subjects, there was a wide scattering and overlapping of the capillary blood pressures for each location in the capillary. This persisted even during procedures (e.g., reflex vasodilatation) designed to produce a standard, reproducible, state of the digital circulation. It is, therefore, difficult to justify general concepts based on average values. The data does, however, indicate the trend of digital capillary blood pressure under a variety of influences.

The digital capillary blood pressure in all locations in the capillary was both qualitatively and

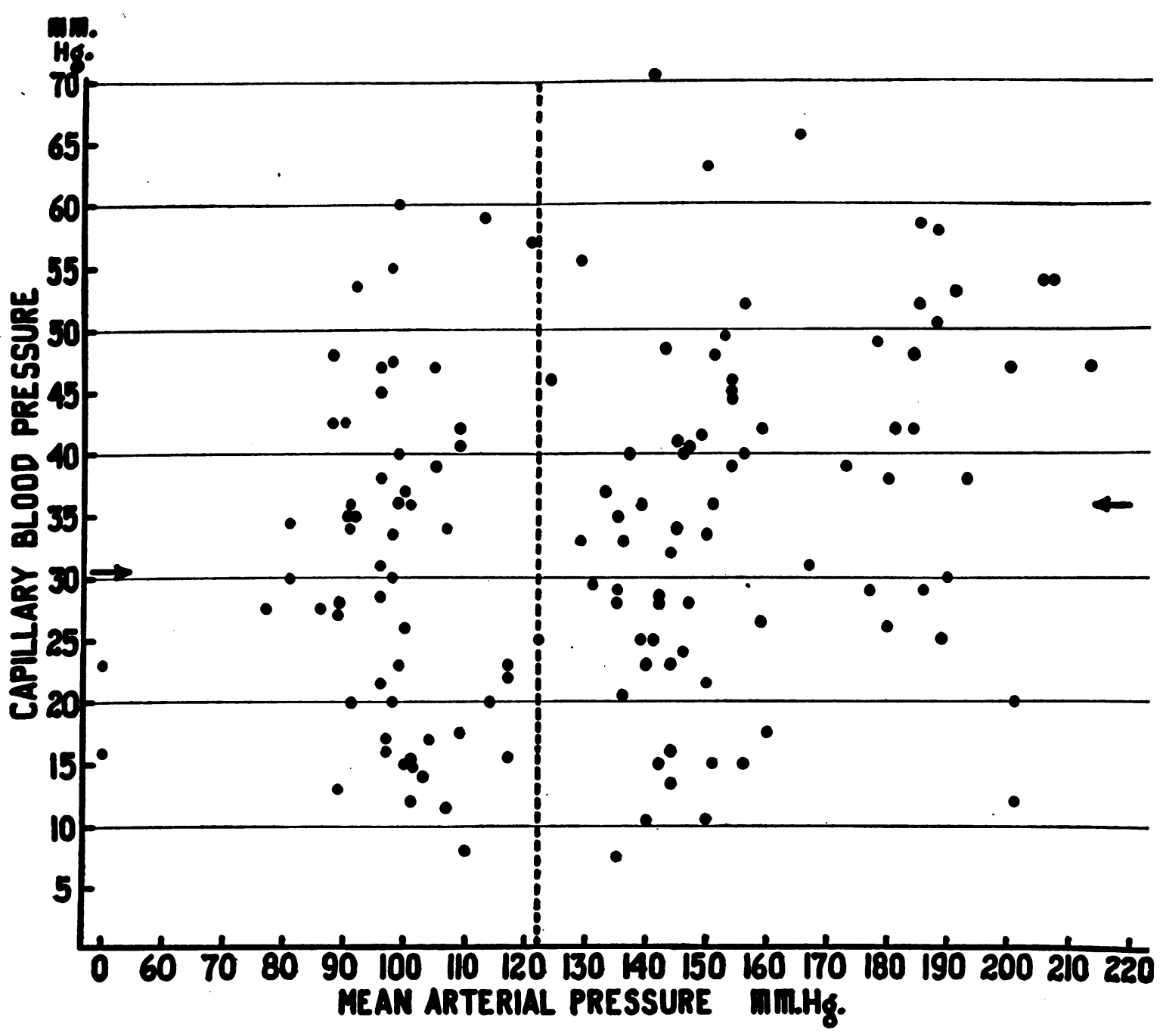

Fig. 8. Digital Capillary Blood Pressure in the Arteriolar limbs of Subjects with Normal Arterial Pressure Compared with Pressures in the Arteriolar Limbs of Hypertensive Patients

The capillary blood pressures vary over the same range in both groups of subjects. Due to multiple aneurysms, the brachial arterial pressure was unobtainable in the subject whose mean arterial pressure is recorded as zero. This does not exclude a substantial non-pulsatile arterial pressure. 


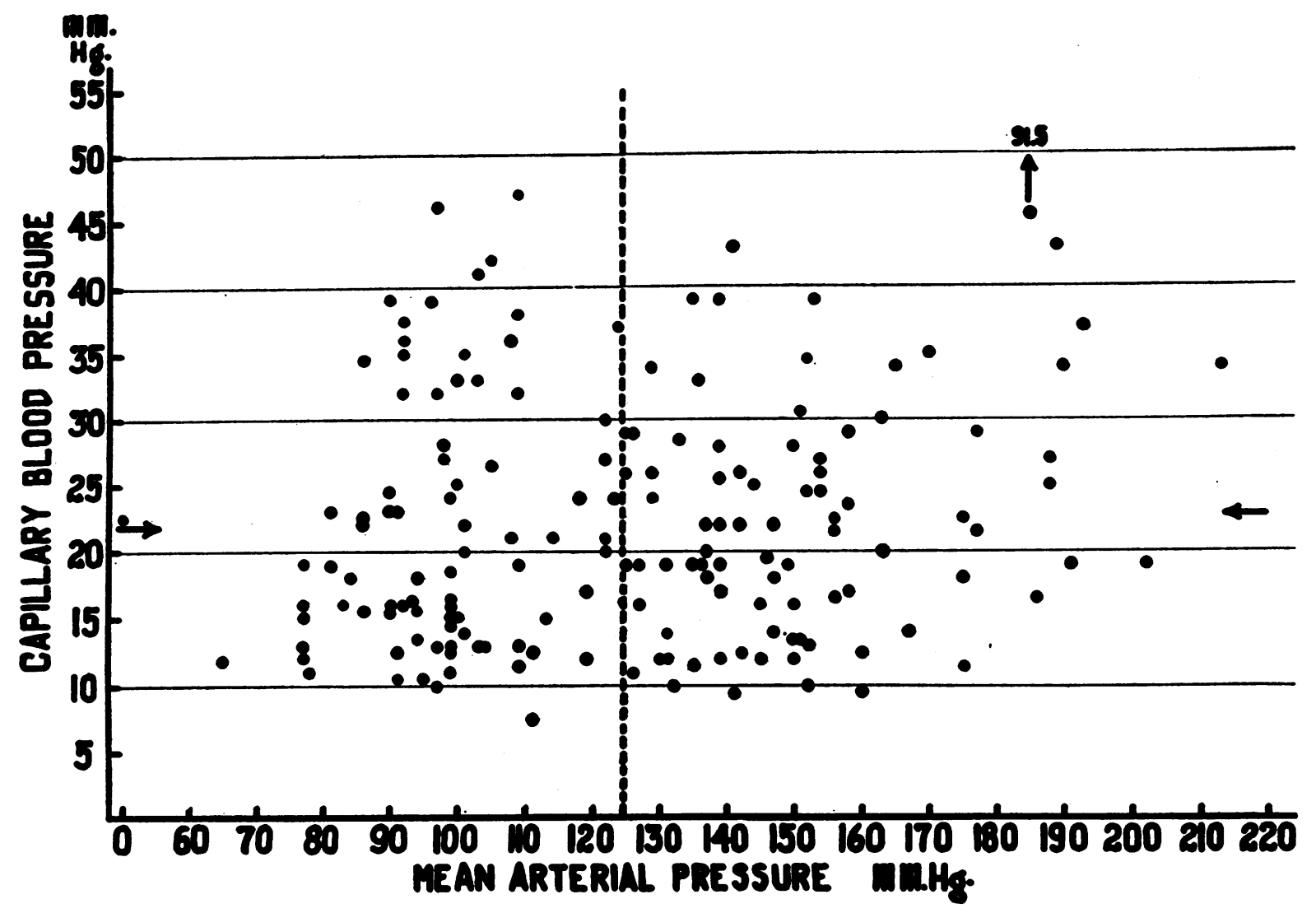

Fig. 9. Digital Capillary Blood Pressure in the Venous limbs of Subjects with Normal Arterial Pressure Compared with Pressures in the Venous Limbs of Hypertensive Patients

The capillary blood pressures vary over the same range in both groups of subjects. The subject whose mean arterial pressure is recorded as zero is the one referred to in Figure 8.

quantitatively similar in the normal and hypertensive subjects, and in the same individual or group, at various levels of blood pressure. This was so not only during the resting state but also during such physiologic influences as neurogenic vasoconstrictions, reactive hyperemia, variations in digital skin temperature between $27^{\circ} \mathrm{C}$. and $35^{\circ} \mathrm{C}$., and reftex vasodilatation. Although these influences are known to alter markedly the blood flow to the digits $(11,12)$, they induced in both normal and hypertensive subjects only comparatively small, and equal, changes (20 per cent to 25 per cent of the initial value) in capillary blood pressure. The resultant values did not fall clearly beyond the limits determined when these influences were not operating. Such changes as did occur were similar in all locations in the capillary, except during reflex vasodilatation, when the pressure in the venous limb of the capillary rose while that in the arteriolar limb remained unchanged. Only by raising the local venous pressure, was the digital capillary blood pressure consistently altered to values beyond the wide normal limits. Venous pressure was not measured in these subjects. Clinically, there was no evidence that it was increased in any subject. The above changes were similar at all ranges of arterial pressure.

The data do not adequately clarify the mechanism by which these physiologic stimuli induce such great changes in digital blood flow without considerable change in capillary blood pressure. Perhaps the arteriole-venule anastomoses constitute one of the factors in this mechanism. By varying the calibre of the arteriole-venule shunts, and thus the amount of blood which by-passes the capillary, physiologic influences could alter considerably the blood flow through the digit without affecting significantly the digital capillary blood 
pressure. Also, the digital blood flow derives from the sum of the flows through a large number of small peripheral vascular units. A relatively small change in a function of each small unit, when multiplied by the large number of units, could account for a considerable change in some function (such as blood flow) of the digit as a whole.

It is significant for the maintenance of the passage of normal amounts of fluid across the capillary membrane that there be a mechanism whereby the capillary blood pressure remains relatively unchanged during the considerable alterations in blood flow which accompany physiologic stimuli. The essentially similar capillary blood pressure in the digits of both normal and hypertensive subjects indicates an increased steepness of the gradient of pressure in the hypertensive subject; and locates it between the artery (elevated pressure) and capillary (normal pressure), presumably in the arteriole. The increased pressure-gradient is apparently due to the increased resistance in the arteriole. This is in harmony with the present concept that the increased general vascular resistance in hypertension is arteriolar in origin. The $\mathbf{5 0}$ per cent greater average gradient of pressure from arteriolar limb to ve- nous limb of the capillary in hypertensive subjects may suggest that the capillaries also contribute to the increased vascular resistance in hypertension. This consideration was discarded because of the wide scattering of values in both groups of subjects and the failure of capillary blood pressure to show any relationship to the arterial pressure. Certainly, the overwhelming portion of the increased vascular resistance in the digits of the hypertensive subjects is arteriolar in origin. These data do not indicate the nature of the increased arteriolar resistance, whether functional (constriction), or the result of some disease process.

If vasodilating procedures relaxed fully the vascular resistance of both hypertensive and normal subjects, then, due to the greater arterial pressure, the capillary blood pressure in the hypertensive subjects should exceed that in normal subjects. The three vasodilating procedures employed, reflex vasodilatation, reactive hyperemia, and histamine injected locally, all produced vasodilatation through relaxation of vascular resistance. These few experiments suggested that only the locally injected histamine appeared to relax, at least to some extent, the increased vas-

TABLE VIII

Capillary blood pressure in the same individual during stages of elevated and lowered arterial pressure

\begin{tabular}{|c|c|c|c|c|c|c|c|c|c|c|c|c|c|c|c|}
\hline \multirow{3}{*}{$\begin{array}{c}\text { Subject } \\
\text { (Bex, } \\
\text { age) }\end{array}$} & \multirow{3}{*}{ Diagnosis } & \multicolumn{6}{|c|}{ Hypertensive stage } & \multicolumn{8}{|c|}{ Stage of lowered blood pressure } \\
\hline & & \multirow{2}{*}{$\begin{array}{l}\text { Skin } \\
\text { tem- } \\
\text { pera- } \\
\text { ture }\end{array}$} & \multicolumn{2}{|c|}{ Arterial preseure } & \multicolumn{3}{|c|}{ Capillary blood preasure } & \multirow{2}{*}{$\begin{array}{l}\text { Shin } \\
\text { tem- } \\
\text { pera- } \\
\text { ture }\end{array}$} & \multicolumn{2}{|c|}{ Arterial presure } & \multicolumn{4}{|c|}{ Capillary blood preasure } & \multirow{2}{*}{$\begin{array}{l}\text { Lowering of arterial } \\
\text { pressure due to }\end{array}$} \\
\hline & & & $\begin{array}{c}\text { Reant- } \\
\text { ing }\end{array}$ & "Mean" & $\begin{array}{l}\text { Arto } \\
\text { riolar } \\
\text { limb }\end{array}$ & $\underset{\text { mit }}{\text { Sum- }}$ & $\begin{array}{c}\text { Venous } \\
\text { limb }\end{array}$ & & $\begin{array}{c}\text { Read- } \\
\text { ing }\end{array}$ & "Mean" & $\begin{array}{l}\text { Arto- } \\
\text { riole }\end{array}$ & $\begin{array}{l}\text { Arto- } \\
\text { riolar } \\
\text { limb }\end{array}$ & $\underset{\text { mit }}{\text { Sum- }}$ & $\begin{array}{c}\text { Venous } \\
\text { limb }\end{array}$ & \\
\hline M. E. & $\begin{array}{l}\text { Eevential } \\
\text { hypertension }\end{array}$ & $\begin{array}{l}{ }^{\circ} \mathrm{C} . \\
29.1\end{array}$ & $\overline{m m . H g}$ & $\begin{array}{c}m m . H g \\
131\end{array}$ & $\overline{m m . H g}$ & $m m . H_{0}$ & $\begin{array}{c}\min . H_{0} \\
14,12\end{array}$ & $\begin{array}{l}\cdot c . \\
33.5\end{array}$ & \begin{tabular}{|l|}
$m m . H g$ \\
$116 / 78$
\end{tabular} & $\underset{97}{\operatorname{mim} . ~ H 0}$ & $\begin{array}{c}m m . H 0 \\
50,56\end{array}$ & $m m . H g$ & $\begin{array}{c}m m . H g \\
26.5\end{array}$ & $\overline{m m . B g}$ & Spontaneous subsidence \\
\hline $\begin{array}{l}\text { E. E. } \\
(\mathbf{F}, 38)\end{array}$ & $\begin{array}{l}\text { Eecontial } \\
\text { hypertension }\end{array}$ & $\begin{array}{l}35.3 \\
34.6\end{array}$ & \begin{tabular}{|l|}
$192 / 114$ \\
$174 / 126$
\end{tabular} & $\begin{array}{l}153 \\
150\end{array}$ & $\frac{49.5}{63}$ & & & $\begin{array}{l}33.1 \\
34.8 \\
34.4 \\
35.4 \\
34.2 \\
\end{array}$ & \begin{tabular}{|l|}
$116 / 94$ \\
$126 / 98$ \\
$112 / 90$ \\
$130 / 108$ \\
$136 / 110$ \\
\end{tabular} & $\begin{array}{l}105 \\
124 \\
101 \\
119 \\
123\end{array}$ & & $\begin{array}{l}38 \\
47\end{array}$ & 30 & $\begin{array}{l}22 \\
17 \\
24\end{array}$ & $\begin{array}{l}\text { Bilateral splanchnic and } \\
\text { lumbar gympathectomy }\end{array}$ \\
\hline J. B. & $\begin{array}{l}\text { Subarachnoid } \\
\text { hemorrhage }\end{array}$ & 31.4 & $182 / 106$ & 144 & $16,13.5$ & 20.5 & & $\begin{array}{l}28.6 \\
28.5\end{array}$ & $\begin{array}{l}148 / 90 \\
136 / 86\end{array}$ & 119 & & $\begin{array}{c}23,32, \\
19.5\end{array}$ & 23,27 & 12 & Bpontaneous subaidence \\
\hline \multirow[t]{2}{*}{$\begin{array}{l}\text { M. W. } \\
(\mathbf{M}, 26)\end{array}$} & $\begin{array}{l}\text { Chronic } \\
\text { pyelone- } \\
\text { phritis }\end{array}$ & 34.2 & $174 / 126$ & 150 & & 20,16 & $\begin{aligned} 20, \\
13.5\end{aligned}$ & $\overline{34.2}$ & $130 / 80$ & 110 & & 8 & & $\begin{array}{c}10,22, \\
14\end{array}$ & Left nephrectomy \\
\hline & & \multicolumn{6}{|c|}{ RLOHT ARY } & \multicolumn{7}{|c|}{ LWT ARM } & . \\
\hline J....4. & $\begin{array}{l}\text { Esecential } \\
\text { hypertension }\end{array}$ & $\begin{array}{l}31.5 \\
32.0 \\
28.9\end{array}$ & $\begin{array}{l}148 / 106 \\
160 / 110 \\
160 / 110\end{array}$ & $\begin{array}{l}127 \\
135 \\
135\end{array}$ & 29 & & $\begin{array}{c}16.19 \\
11.5\end{array}$ & \begin{tabular}{l|}
32.7 \\
33.2 \\
32.2 \\
33.3
\end{tabular} & $\underset{\substack{\text { not } \\
\text { obtain- } \\
\text { able }}}{\mid}$ & & & 17.5 & & \begin{tabular}{|c|}
7.5 \\
12.5 \\
19.13 \\
11.5
\end{tabular} & $\begin{array}{l}\text { Local arterial disease } \\
\text { rendered left arm pulso } \\
\text { lese }\end{array}$ \\
\hline
\end{tabular}


cular resistance of the hypertensive subjects, whereas reflex vasodilatation and reactive hyperemia did not. Only during the hyperemia of histamine did the capillary blood pressure in the hypertensive exceed that in the normal subject. During the physiologically induced vasodilatations of reactive hyperemia and reflex vasodilatation, the capillary blood pressure was essentially equal in the two groups. The data do not indicate whether the relaxation of the increased vascular resistance by histamine was complete or partial.

In both normal and hypertensive subjects, these three vasodilating procedures caused a disproportionately great rise in the capillary blood pressure in the venous limb. As a result, the increased digital blood flow of vasodilatation was accompanied by a lower gradient of pressure through the capillaries of the digit. Apparently, digital blood flow need not be proportional to the gradient of digital capillary blood pressure, and may be more closely dependent upon the patency of the arteriolevenule anastomoses. Dilatation of these structures would increase the digital blood flow and, by raising the blood pressure in the venous limb of the capillary, reduce the gradient of pressure through the capillary.

These studies suggest that there are mechanisms which maintain the digital capillary blood pressure within certain limits. These limits appear not to be exceeded during the considerable changes in digital blood flow which result from the action of certain physiologic influences. Nor are these limits exceeded when a disease process, such as essential hypertension, markedly alters the pressure in the arteries.

\section{SUM MARY}

1. The digital capillary blood pressure for all locations in the capillary varied within wide limits, and was qualitatively and quantitatively similar in both normal and hypertensive subjects. This maintained during the following observations which apply equally to both groups of subjects.

a. Such physiologic influences as neurogenic vasoconstrictions, reactive hyperemia, reflex vasodilatation, and variations in skin temperature between $27^{\circ} \mathrm{C}$. and $35^{\circ} \mathrm{C}$., all induced such comparatively small changes in the digital capillary blood pressure that the resultant values did not fall beyond "resting" limits. These changes were considerably smaller than the much larger alterations in digital blood flow known to occur under similar circumstances.

b. Only during increases in local venous pressure did the digital capillary blood pressure consistently exceed "resting" values.

c. Wide variations in digital capillary blood pressure persisted during reflex vasodilatation, a state during which digital circulation is considered to be full, standard, and reproducible.

d. During vasodilatation, induced reflexly or by locally injected histamine, there was a disproportionately greater increase in pressure in the venous limb than elsewhere in the capillary. The other states all influenced equally the digital capillary blood pressure in all locations of the capillary.

2. No correlation existed between the digital capillary blood pressure and the arterial pressure, except perhaps during the hyperemia induced by histamine.

3. Some mechanism maintains the digital capillary blood pressure within relatively fixed limits, even during marked changes in digital blood flow and arterial pressure.

4. The similarity of the digital capillary blood pressure of normal and hypertensive subjects indicates that in the digits the increased vascular resistance of hypertensive subjects is precapillary, presumably arteriolar.

5. During the vasodilatation of reactive hyperemia and reflex vasodilatation, the digital capillary blood pressure was essentially equal in both normal and hypertensive subjects; during vasodilatation induced by locally injected histamine, the capillary pressure of the hypertensive subjects exceeded that in normal subjects. These few experiments may suggest that in the digits histamine appeared to relax, at least to some extent, the increased vascular resistance of hypertension, whereas reactive hyperemia and reflex vasodilatation did not.

6. These data and the conclusions derived therefrom apply only to the capillary blood pressure in the nail-folds of the fingers.

The authors gratefully acknowledge their indebtedness to Mr. William A. Oktavec, Jr., for making the micropipettes and for his constant and most helpful assistance in this study. 


\section{BIBLIOGRAPHY}

1. Weiss, S., and Ellis, L. B., The quantitative aspects and dynamics of the circulatory mechanism in arterial hypertension. Am. Heart J., 1930, 5, 448.

2. Boas, E. P., and Frant, S., Capillary blood pressure in arterial hypertension. Arch. Int. Med., 1922, 30, 40.

3. Boas, E. P., and Mufson, I., Capillary blood pressure in arterial hypertension and nephritis. J. Lab. and Clin. Med., 1923, 9, 152.

4. Ellis, L. B., and Weiss, S., Measurements of capillary pressure under natural conditions and after arteriolar dilatation in normal subjects and in patients with arterial hypertension and with arteriosclerosis. J. Clin. Invest., 1929, 8, 47.

5. Mufson, I., Study of capillary pressure in nephritis and hypertension. Am. J. M. Sc., 1932, 183, 632.

6. Eichna, L. W., and Bordley, J., III, Capillary blood pressure in man. Comparison of direct and indirect methods of measurement. J. Clin. Invest., 1939, 18, 695.
7. Landis, E. M., Microinjection studies of capillary blood pressure in human skin. Heart, 1930, 15, 209.

8. Eichna, L. W., and Wilkins, R. W., Capillary blood pressure in man. Direct measurements in the digits during induced vasoconstriction. J. Clin. Invest., 1942, 21, 697.

9. Adson, A. W., Craig, W. M., and Brown, G. E., Surgery in its relation to hypertension. Surg., Gynec. and Obst., 1936, 62 (2A), 314.

10. Grant, R. T., and Bland, E. F., Observations on arteriovenous anastamoses in human skin and in the bird's foot with special reference to the reactions to cold. Heart, 1931, 15, 385.

11. Wilkins, R. W., Doupe, J., and Newman, H. W., The rate of blood flow in normal fingers. Clin. Sc., 1938, 3, 403.

12. Burton, A. C., The range and variability of the blood flow in the human fingers and the vasomotor regulation of body temperature. Am. J. Physiol., 1939, 127, 437. 